This document is confidential and is proprietary to the American Chemical Society and its authors. Do not copy or disclose without written permission. If you have received this item in error, notify the sender and delete all copies.

\title{
Development of cyclic NGR-peptides with thioether linkage: structure and dynamics determining deamidation and bioactivity
}

\begin{tabular}{|r|l|}
\hline Journal: & Journal of Medicinal Chemistry \\
\hline Manuscript ID: & Draft \\
\hline Manuscript Type: & Article \\
\hline Date Submitted by the Author: & $\mathrm{n}$ a \\
\hline List of Authors: & $\begin{array}{l}\text { Enyedi, Kata; MTA-ELTE, Research Group of Peptide Chemistry } \\
\text { Czajlik, András; Pázmány Péter Catholic University, Faculty of Information } \\
\text { Technology } \\
\text { Knapp, Krisztina; Eötvös Loránd University, Laboratory for Chiroptical } \\
\text { Structure Analysis, Institute of Chemistry } \\
\text { Láng, András; Eötvös Loránd University, Institute of Chemistry } \\
\text { Majer, Zsuzsa; Eötvös Loránd University, Laboratory for Chiroptical } \\
\text { Structure Analysis, Institute of Chemistry } \\
\text { Lajkó, Eszter; Semmelweis University, Department of Genetics, Cell and } \\
\text { Immunobiology } \\
\text { Kőhidai, László; Semmelweis University, Department of Genetics, Cell and } \\
\text { Immunobiology } \\
\text { Perczel, András; Institute of Chemistry, Eötvös Loránd University, } \\
\text { Laboratory of Structural Chemistry and Biology } \\
\text { Mezõ, Gábor; Hungarian Academy of Sciences, Research Group of Peptide } \\
\text { Chemistry }\end{array}$ \\
\hline \hline
\end{tabular}

\section{SCHOLARONE ${ }^{\text {Im }}$}

Manuscripts 


\title{
Development of cyclic NGR-peptides with thioether linkage: structure and
}

\section{dynamics determining deamidation and bioactivity}

\author{
Kata Nóra Enyedi, ${ }^{\#, \S}$ András Czajlik, ${ }^{\ddagger,+}$ Krisztina Knapp, ${ }^{\vee}$ \\ András Láng,,${ }^{\S}{ }^{\perp}$ Zsuzsa Majer, ${ }^{\vee}$ Eszter Lajkó, ${ }^{\dagger}$ László Kőhidai, ${ }^{\dagger}$ András Perczel, ${ }^{\S}, \perp$ and \\ Gábor Mezö\#,*
}
${ }^{\#}$ MTA-ELTE Research Group of Peptide Chemistry, Hungarian Academy of Sciences, Eötvös Loránd University, Pázmány P. sétány. 1/A, 1117 Budapest, Hungary
${ }^{\dagger}$ Faculty of Information Technology, Pázmány Péter Catholic University, Práter u. 50/A, 1083 Budapest, Hungary

${ }^{+}$Research Group for Neurodegenerative Disease Drug Discovery, Research Center for Natural Sciences, Institute of Organic Chemistry, Hungarian Academy of Sciences, Magyar tudósok körútja 2.,1117 Budapest, Hungary

${ }^{\vee}$ Laboratory for Chiroptical Structure Analysis, Institute of Chemistry, Eötvös Loránd University, Pázmány P. sétány. 1/A, 1117 Budapest, Hungary

${ }^{\S}$ Laboratory of Structural Chemistry and Biology, Institute of Chemistry, Eötvös Loránd University, Pázmány P. sétány. 1/A, 1117 Budapest, Hungary

${ }^{\perp}$ MTA-ELTE Protein Modelling Research Group, Hungarian Academy of Sciences, Eötvös Loránd University, Pázmány P. sétány 1/A, 1117 Budapest, Hungary

${ }^{\dagger}$ Department of Genetics, Cell and Immunobiology, Semmelweis University, Nagyvárad tér 4, 1089 Budapest, Hungary 


\begin{abstract}
In drug targeting NGR-peptides recognized by CD13 receptors on tumor neovasculature have got improved interest. Here we present the synthesis and structure analysis of novel thioether linked cyclic NGR-peptides. We found that chemo-stability (resistance against spontaneous decomposition forming isoAsp and Asp derivatives) strongly depends both on sample handling conditions and structural properties. Significant correlation was found between chemo-stability and structural measures: e.g. $\mathrm{NH}^{\mathrm{Gly}}$... CO $\mathrm{C}^{\mathrm{Asn}-\mathrm{sc}}$ distances. Side chain orientation of Asn is the key determining factor, if turned away from $\mathrm{HN}^{\mathrm{Gly}}$ chemo-stability increases. Structure stabilizing factors (e.g. H-bond(s)) lower their internal dynamics and thus macromolecules become even more resistant against spontaneous decomposition. Effect of cyclic NGR-peptides on cell adhesion was examined on A2058 melanoma cell lines. It was found that some of them gradually increased the cell adhesion with long term characteristics indicating the time-dependent formation of integrin binding isoAsp derivatives, responsible for the adhesion inducing effect.
\end{abstract}




\section{INTRODUCTION}

Attention turned to NGR (Asn-Gly-Arg) peptides when non-RGD (Arg-Gly-Asp) integrin binding motifs were searched via phage display libraries. ${ }^{1,2}$ NGR motif was the most frequent one among them that shows integrin binding propensities. NGR sequence containing peptides were also selected as tumor vasculature homing peptides from in vivo phage-display screening assay on human breast carcinoma xenografts bearing nude mice. ${ }^{3}$ However, this study also indicated that the cyclic ACDCRGDCFC peptide (RGD-4C containing 1-4 and 2-3 disulfide bridge isomer) did not compete with the CNGRC (NGR-2C) cyclic peptide in tumor-homing properties and vice versa. Later, aminopeptidase-N (APN or CD13) was recognized as the receptor that binds NGR-peptides. ${ }^{4} \mathrm{CD} 13$, a membrane-bound metallopeptidase, is not (or barely) expressed on endothelium of normal blood vessels but it is up-regulated in angiogenic blood vessels and has multiple functions (e.g. protein degradation, cell proliferation, cell migration, angiogenesis). ${ }^{4-6}$ Furthermore, CD13 is also expressed by various cell types (e.g. liver, prostate, kidney) in healthy individuals. However, it was indicated by the aid of different anti-CD13 monoclonal antibodies that the immunoreactivity of CD13 containing tumor and normal endothelia cell lines are markedly different. ${ }^{5,7}$ This might originate from different glycosylation pattern and/or receptor isoform conformations. This observation makes CD13 a suitable target molecule for specific targeted delivery of drugs and nanoparticles to tumor neovasculature, using NGR-peptides as a homing motif. ${ }^{8,9}$

It is well known, that Asn deamidation through succinimide ring formation can easily occur, especially if Asn is followed by Gly on its $C$-terminus. ${ }^{10,11}$ This non-enzymatic intramolecular reaction finally leads to the formation of isoaspartyl (isoAsp) and aspartyl (Asp) containing peptides of about 3:1 ratio, and depends on $\mathrm{pH}$, temperature, solvent dielectric constant, primary sequence and secondary structural motives. This modification causes difficulties on in vitro and in vivo biological data interpretation as well as on NGR-peptide 
formulation. ${ }^{12}$ Furthermore, this non-enzymatic post-translational modification could be responsible for the integrin binding properties of NGR sequence containing peptides and proteins. It was shown that cyclic and linear peptides with isoAsp-Gly-Arg sequence can bind to $\alpha_{v} \beta_{3}, \alpha_{v} \beta_{5}, \alpha_{v} \beta_{6}, \alpha_{v} \beta_{8}$ and $\alpha_{5} \beta_{1}$ integrins while peptides with Asp-Gly-Arg sequence not. ${ }^{13}$ Therefore, stability studies of linear and cyclic NGR-peptides used as tumor-homing motives are crucial before developing such drug delivery systems.

There are several publications that present the deamidation of NGR-peptides under different circumstances. The main results are summarized as follows. i) Deamidation proceeds via deprotonation of the peptide bond (at $\mathrm{pH}>5.0$ ) located at the $C$-terminal side of Asn. ii) The subsequent nucleophilic attack on the $\mathrm{CO}$ of Asn side chain leads to a succinimid ring formation (Asu), stabilized afterwards by the elimination of $\mathrm{NH}_{3}$. iii) The relatively unstable Asu-peptide can hydrolyze resulting in an ensemble of isoAsp and Asp containing peptides, easy to characterize by MS (+1 Da compared to that of the Asn derivative). iv) As the initial step of ring closure is a deprotonation, $\mathrm{pH}$ increase elevates deamidation rate. ${ }^{14}$ Interestingly, deamidation is more pronounced in buffer solutions even at around neutral $\mathrm{pH}$ than it is in water. $^{12,13,15}$ In a liophylized form or in pure water at low temperature deamidation rate is insignificantly low. ${ }^{13}$ However, at elevated temperature or in buffer rate increases considerably. ${ }^{10,12}$ This rearrangement is lower in proteins if NGR is located in a buried and highly structured part ( $\alpha$-helical or $\beta$-turn) of the polypeptide chain. ${ }^{16,17}$ However, the very same reaction is faster $(\sim 30$-fold $)$ if Asn of NGR is located at the $(i+1)$ but not in the $(i+2)$ position of a $\beta$-turn. ${ }^{18}$ Capasso et al. demonstrated that if Lys residue is preceding NG, then it further increases deamidation rate, especially in cyclic peptides e.g. Ac-c[CKNGQTNC]- $\mathrm{NH}_{2}$ independent whether the side chain of Lys is acetylated or not. ${ }^{19}$ Plesniak et al. investigated the Pro containing c[CPNGRC] hexapepide ${ }^{20}$ and found that at higher $\mathrm{pH}$ and temperature 
$\left(\mathrm{pH} 8.5,37^{\circ} \mathrm{C}\right.$ ) within $2 \mathrm{~h}$ a significant deamidation is observed. Interestingly, the latter cyclic hexapeptide have 30 times higher binding affinity to CD13 with respect to c[CNGRC].

A few of the linear and cyclic NGR-peptides were used for ligand-directed delivery of various drugs and particles to tumor vessels, an attempt to increase their antitumor activity. ${ }^{7}$ Cyclic and/or linear peptides containing either the c[CNGRC] or the GNGRG motives were described as appropriate target ligands in delivery of tumor necrosis factor alpha (TNF$\alpha),{ }^{5,21,22}$ interferon gamma (IFN $\left.\gamma\right),{ }^{23-25}$ liposomal doxorubicin ${ }^{26,27}$ and Pt-complex ${ }^{28,29}$ as well as radio metal isotope labeled derivatives for PET and SPECT. ${ }^{30,31}$ By comparing c [CNGRC] and GNGRG, a cyclic and a linear peptide, not only the higher CD13 binding affinity of cyclic variant was detected but also its increased stability in PBS solution (half-lives were 6-8 $\mathrm{h}$ and $3-4 \mathrm{~h}$, respectively at $\left.\mathrm{pH} 7.3,37^{\circ} \mathrm{C}\right)$ and in serum $(5 \mathrm{~h}$ and $3 \mathrm{~h}$, respectively) was measured. ${ }^{13}$ However, chemo-stability of NGR-peptides under relevant biological conditions is not studied.

Efficient development of disulfide bridge containing cyclic NGR (e.g. c[CNGRC]) peptides on the surfaces of liposomes or other nanoparticles used for drug targeting is not an easy task. Therefore, to date mainly less chemo-stable linear NGR-peptides were used for active targeting of anticancer drugs encapsulated by nanoparticles. ${ }^{32}$ Negussie et al. successfully developed a head-to-side chain cyclic NGR-peptide. ${ }^{33}$ In the c[KNGRE]-NH peptide the $\alpha$-amino group of the $N$-terminus and the side chain carboxyl group of Glu were attached by using on resin cyclization. The resulted ring size of the 17-atom-containing macrocycle is identical to that of $\mathrm{c}[\mathrm{CNGRC}]$ with disulfide bond. Their goal was to investigate an NGR homing motif with increased stability for delivery of free or liposome encapsulated drugs. In this way, the formation of disulfide bonds between the adjacent peptides on the liposome surface rendering the ligand ineffective could be avoided. ${ }^{34}$ The free $\varepsilon$-amino group of Lys was used for the attachment of Oregon Green fluorescent label or the 
liposome that did not influence the binding to CD13. The $\mathrm{c}[\mathrm{KNGRE}]-\mathrm{NH}_{2}$ ligand displayed 3.6-fold higher affinity for CD13 positive cancer cells than the linear KNGRG did. However, the deamidation of these analogs were not studied in this experiment.

Since the intact cyclic NGR-peptides could bind to CD13, deamidation resulting in isoaspartyl (isoAsp) metabolite might restrict the application of the cyclic NGR-peptides as successful tumor-homing moieties. Nevertheless, the formed isoAsp derivatives could be responsible for integrin binding, which integrins are also over-expressed in several types of tumors. $^{35}$ Therefore, appropriate cyclic NGR-peptide conjugates might be dual acting derivatives through both $\mathrm{CD} 13$ and integrin receptors. ${ }^{36}$

In our previous study, it was indicated that the enzymatic stability of cyclic epitope peptide could be increased when thioether linkage was used instead of amide- or disulfide bond. ${ }^{37}$ Furthermore chloroacetylated peptides with orthogonal protecting groups on two cysteines are suitable for cyclization and conjugation to a carrier via thioether bond formation in both cases. ${ }^{38}$

In accordance with the observations described above, in this study our aim was $a$ ) to develop novel thioether linked cyclic NGR-peptides of different ring size (15-18 atoms of the cycle); b) to study the structure - stability (rate of deamidation) relationship of these compounds; c) to verify the rearrangement of NGR to isoDGR by measurement of the time dependent effect on cell adhesion of A2058 melanoma cell line as an essential functional index of integrin receptor mediated tumor targeting; and d) to compare the data with the results of cyclic Ac-c[CNGRC]- $\mathrm{NH}_{2}$ and $\mathrm{c}[\mathrm{KNGRE}]-\mathrm{NH}_{2}$ derivatives known from the literature. 


\section{RESULTS}

\section{Synthesis of the cyclic NGR-peptides}

Cyclic NGR-peptides with amide-, disulfide- and thioether bond were synthesized by development of the precursor linear peptides on Rink-Amide MBHA resin with standard Fmoc/tBu strategy. Cyclization was carried out in solution. i) Preparation of cyclic peptide comprising an amide bond a Glu derivative was introduced to the $C$-terminus of the NGR sequence and a Boc-Lys(ClZ)-OH amino acid derivative was attached to its $N$-terminus. The standard TFA cleavage resulted in semi-protected H-Lys(ClZ)-Asn-Gly-Arg-Glu-NH${ }_{2}$, which was subsequently cyclized: the amide bond is formed between the $N$-terminus and the side chain of Glu by using BOP/HOBt coupling reagents. Finally, the ClZ protecting group was removed using liquid HF before HPLC purification of c[KNGRE]-NH $\mathrm{NH}_{2}$ (1). ii) The cyclic NGR-peptide (Ac-c[CNGRC]-NH $\mathrm{NH}_{2}$ (2)) bridged with a disulfide bond designed by placing two Cys at both ends of -NGR- and subsequently acetylated at its $N$-terminus. The disulfide bridge was formed either by using a Trt SH-protecting group for Cys, residues removed by TFA, cyclized at slightly alkaline conditions $(0.1 \mathrm{M}$ Tris buffer at $\mathrm{pH} 8.1$ for $24 \mathrm{~h}$ or $48 \mathrm{~h})$, or by using Acm SH-protection for cysteines, completed with a cyclization in TFA in the presence of $\mathrm{Tl}(\mathrm{tfa})_{3}$. Deamidation and isoAsp-containing peptide formation were observed under alkaline conditions; the longer reaction time resulted in higher yield of isoAsp containing peptide. On the contrary, under acidic condition no deamidation of Asn was observed, resulting in the highest yield of compound 2. iii) Cyclic NGR-peptides with thioether linkage of cysteine were made by putting a Cys at the $C$-terminus of the NGR sequence, while its $N$-terminus was modified with $\alpha$ - or $\beta$-haloacyl group. Chloroacetylated XNGRC peptides $(\mathrm{X}=\varnothing$, Lys or Pro) were cyclized in $0.1 \mathrm{M}$ Tris buffer ( $\mathrm{pH} 8.1$ ): reaction was fast (completed within $3 \mathrm{~h}$ ) at a good yield. Only a moderate deamidation was detected during these reaction conditions yielding compounds 3-5 $\left(\mathrm{c}\left[\mathrm{CH}_{2} \mathrm{CO}-\mathrm{XNGRC}\right]-\mathrm{NH}_{2}: \mathrm{X}=\varnothing\right.$ 
(3), Lys (4) or Pro (5)). Unlike the above two cyclic compounds (1 and 2), both having in total 17, compound $\mathbf{3}$ contains 15, while $\mathbf{4}$ and $\mathbf{5} 18$ atoms within the macrocycle, respectively. $i v$ ) A "methylene elongated" derivative of $3\left(\mathrm{c}\left[\mathrm{CH}_{2} \mathrm{CH}_{2} \mathrm{CO}-\mathrm{NGRC}\right]-\mathrm{NH}_{2}(\mathbf{6})\right)$ was designed to contain 16 atoms within the macrocycle, closing the NGR subunit within a ring. The reaction of the protected parent NGRC peptide on the solid support with $\beta$-halopropionic acid (chloroor bromo-) did not give complete blocking of the $\mathrm{N}$-terminal $\mathrm{NH}_{2}$-group. Since cyclization of the chloroacylated derivative was slow, meanwhile a significant ratio of the product converted into isoAsp-containing derivative. The latter side reaction was less pronounced for the bromoacylated derivative, as cyclization was completed within less than $3 \mathrm{~h}$ and thus, compound was not exposed to alkaline condition for such a long time. v) Finally, as $N$ terminal chloroacetylation of the parent linear peptide was straightforward than the attachment of $\beta$-halopropionyl group, the thioether bond formation was achieved as follows. A homoCys was incorporated to the $C$-terminus of the NGR parent peptide and its $N$-terminus was chloroacetylated and cyclization was completed in $3 \mathrm{~h}(0.1 \mathrm{M}$ Tris buffer, $\mathrm{pH}$ 8.1). The $\mathrm{c}\left[\mathrm{CH}_{2} \mathrm{CO}-\mathrm{NGR} h \mathrm{C}\right]-\mathrm{NH}_{2}$ (7) containing 16-atom-cycle was synthesized with a much better yield (37.9\%) than by using the previous strategy via the bromopropionylated precursor for preparation of compound $6(17.1 \%)$. (Note that the application of $\gamma$-bromobutiric acid for the formation of the 17-membered ring closed by a thioether bond was unsuccessful.) The characteristics of the cyclic peptides are summarized in Table 1 and the HPLC chromatograms and mass spectra of the purified cyclic peptides are presented in the Supporting Information (Figure S1). 
Table 1. Characteristic analytical information of the cyclic NGR-peptides ${ }^{\text {a }}$

\begin{tabular}{|l|c|c|c|c|}
\hline \multicolumn{1}{|c|}{ Compounds } & Yield (\%) & $\mathbf{R}_{\mathbf{t}}(\mathbf{m i n})^{\mathbf{b}}$ & $\mathbf{M w}_{\text {calc }} \mathbf{c}^{\mathbf{}}$ & $\mathbf{M w}_{\text {found }} \mathbf{d}^{\mathbf{d}}$ \\
\hline $\mathrm{c}[\mathrm{KNGRE}]-\mathrm{NH}_{2}(\mathbf{1})$ & 46.2 & 12.0 & 583.3 & 583.4 \\
\hline $\mathrm{Ac}-\mathrm{c}[\mathrm{CNGRC}]-\mathrm{NH}_{2}(\mathbf{2})$ & 45.3 & 15.8 & 590.2 & 590.4 \\
\hline $\mathrm{c}\left[\mathrm{CH}_{2} \mathrm{CO}-\mathrm{NGRC}\right]-\mathrm{NH}_{2}(\mathbf{3})$ & 59.1 & 13.2 & 487.2 & 487.4 \\
\hline $\mathrm{c}\left[\mathrm{CH}_{2} \mathrm{CO}-\mathrm{KNGRC}\right]-\mathrm{NH}_{2}(\mathbf{4})$ & 62.3 & 12.7 & 615.4 & 615.8 \\
\hline $\mathrm{c}\left[\mathrm{CH}_{2} \mathrm{CO}-\mathrm{PNGRC}\right]-\mathrm{NH}_{2}(\mathbf{5})$ & 59.4 & 15.3 & 584.2 & 584.4 \\
\hline $\mathrm{c}\left[\mathrm{CH}_{2} \mathrm{CH}{ }_{2} \mathrm{CO}-\mathrm{NGRC}\right]-\mathrm{NH}_{2}(\mathbf{6})$ & $17.1(7.0)^{\mathrm{f}}$ & 13.0 & 501.2 & 501.3 \\
\hline $\mathrm{c}\left[\mathrm{CH}_{2} \mathrm{CO}-\mathrm{NGR} h \mathrm{C}\right]-\mathrm{NH}_{2}(\mathbf{7})$ & 37.9 & 13.3 & 501.2 & 501.3 \\
\hline
\end{tabular}

${ }^{a}$ Chromatograms and spectra can be found in Supporting Information. ${ }^{b}$ HPLC column: Phenomenex Luna (250 mm $\times 4.6 \mathrm{~mm})$ with $5 \mu$ silica (100A pore size); Eluents: $0.1 \% \mathrm{TFA} /$ water $(\mathrm{A}), 0.1 \% \mathrm{TFA} / \mathrm{CH}_{3} \mathrm{CN}$-water $(80: 20$, v/v) (B); Gradient: 0 min 0\% B, 5 min 0\% B, 50 min 90\% B; Flow rate: $1 \mathrm{~mL} / \mathrm{min}$; Detection: $214 \mathrm{~nm}$. ${ }^{c}$ Monoisotopic mass. ${ }^{d}$ ESI-MS: Bruker Daltonics Esquire 3000+ ion trap mass spectrometer. ${ }^{e}$ Total yields in case of the cyclization with $\mathrm{Tl}(\mathrm{tfa})_{3}$ or by air oxidation for $24 \mathrm{~h}$ or $48 \mathrm{~h}$ (in brackets). ${ }^{f}$ Total yields in case of cyclization from bromo- or chloro- (in brackets) derivatives of precursor peptide.

\section{Chemo-stability of cyclic NGR-peptides}

Stability of the cyclic NGR-peptides was conducted under three different conditions, namely i) their liophylized form was stored at $4^{\circ} \mathrm{C}, i i$ ) dissolved in pure water and in different buffers at $25^{\circ} \mathrm{C}$ (room temperature) and iii) kept in a cell culture medium at $37^{\circ} \mathrm{C}$. The stability of the compounds was followed by analytical RP-HPLC and the decomposition was calculated from AUC (area under the curve). None of these cyclic NGR-peptides, 1-7, decomposed under storage for about 6 months. In addition they were found to be stable in distilled or slightly acidic water (eluent A used for HPLC) at RT for about $48 \mathrm{~h}$. Prior to summarize the further stability studies, it has to be mentioned that in case of the Pro-containing derivative (5) the aspartyl cyclic peptide was the main deamidated product instead of isoaspartyl one. The Asp- 
containing derivative was determined by the aid of synthetic reference peptide as in all cases that were prepared similarly as the cyclic NGR-peptides. The exact amount of isoAsp derivative formed from compound $\mathbf{5}$ could not be analyzed properly (especially not in cell culture medium) because it appears as a broad shoulder of $\mathbf{5}$, that cannot be baseline separated. The stability of the cyclic peptides was also studied in three different buffers. (Data are summarized in Table 2 and chromatograms are presented in Supporting Information (Figure S2-S8)).

Table 2. Chemo-stability of the cyclic NGR-peptides measured by HPLC

\begin{tabular}{|c|c|c|c|c|}
\hline Compounds & $\begin{array}{c}\text { 0.2 } \mathrm{M} \mathrm{NH}_{4} \mathrm{OAc} \\
(\mathrm{pH} \mathrm{5.0)} \\
\text { Asn/isoAsp/Asp }\end{array}$ & $\begin{array}{c}\text { PBS solution } \\
\text { (pH 7.4) } \\
\text { Asn/isoAsp/Asp }\end{array}$ & $\begin{array}{c}\text { 0.1M Tris } \\
\text { (pH 8.1) } \\
\text { Asn/isoAsp/Asp }\end{array}$ & $\begin{array}{c}\text { DMEM } \\
\text { medium } \\
\text { Asn/isoAsp/Asp }\end{array}$ \\
\hline $\mathrm{c}[\mathrm{KNGRE}]-\mathrm{NH}_{2}(\mathbf{1})$ & $100 / 0 / 0^{\mathrm{a}}$ & $100 / 0 / 0$ & $100 / 0 / 0$ & $\begin{array}{l}54 / 39 / 7 \\
(92 / 7 / 1)\end{array}$ \\
\hline Ac-c $[\mathrm{CNGRC}]-\mathrm{NH}_{2}(2)$ & $100 / 0 / 0$ & $\begin{array}{l}93 / 5 / 2 \\
(96 / 3 / 1)\end{array}$ & $\begin{array}{c}71 / 21 / 8 \\
(85 / 11 / 4)\end{array}$ & $\begin{array}{c}0 / 72 / 28 \\
(46 / 38 / 16)\end{array}$ \\
\hline $\mathrm{c}\left[\mathrm{CH}_{2} \mathrm{CO}-\mathrm{NGRC}\right]-\mathrm{NH}_{2}(\mathbf{3})$ & $\begin{array}{c}67 / 26 / 7 \\
(85 / 12 / 3)^{b}\end{array}$ & $\begin{array}{c}15 / 68 / 17 \\
(36 / 51 / 13)\end{array}$ & $\begin{array}{c}13 / 69 / 18 \\
(19 / 57 / 24)\end{array}$ & $(0 / 68 / 32)$ \\
\hline $\mathrm{c}\left[\mathrm{CH}_{2} \mathrm{CO}-\mathrm{KNGRC}\right]-\mathrm{NH}_{2}(4)$ & $\begin{array}{c}90 / 8 / 2 \\
(100 / 0 / 0)\end{array}$ & $\begin{array}{c}43 / 34 / 23 \\
(58 / 23 / 19)\end{array}$ & $\begin{array}{c}15 / 52 / 33 \\
(36 / 41 / 23)\end{array}$ & $(0 / 64 / 36)$ \\
\hline $\mathrm{c}\left[\mathrm{CH}_{2} \mathrm{CO}-\mathrm{PNGRC}\right]-\mathrm{NH}_{2}(\mathbf{5})$ & $\begin{array}{c}98 / 0 / 2 \\
(100 / 0 / 0)\end{array}$ & $\begin{array}{c}75 / 3 / 22 \\
(86 / 2 / 12)\end{array}$ & $\begin{array}{c}47 / 5 / 48 \\
(67 / 3 / 30)\end{array}$ & n.d. ${ }^{\mathrm{c}}$ \\
\hline $\mathrm{c}\left[\mathrm{CH}_{2} \mathrm{CH}_{2} \mathrm{CO}-\mathrm{NGRC}\right]-\mathrm{NH}_{2}(\mathbf{6})$ & $\begin{array}{c}99 / 1 / 0 \\
(100 / 0 / 0)\end{array}$ & $\begin{array}{c}89 / 8 / 3 \\
(94 / 5 / 1)\end{array}$ & $\begin{array}{c}73 / 19 / 8 \\
(86 / 10 / 4)\end{array}$ & $(0 / 70 / 30)$ \\
\hline $\mathrm{c}\left[\mathrm{CH}_{2} \mathrm{CO}-\mathrm{NGR} h \mathrm{C}\right]-\mathrm{NH}_{2}(\mathbf{7})$ & $\begin{array}{l}96 / 3 / 1 \\
(100 / 0 / 0)\end{array}$ & $\begin{array}{l}44 / 43 / 13 \\
(64 / 28 / 8)\end{array}$ & $\begin{array}{l}43 / 45 / 12 \\
(66 / 27 / 7)\end{array}$ & $(0 / 73 / 27)$ \\
\hline
\end{tabular}

${ }^{a}$ The ratio of the Asn, isoAsp and Asp containing cyclic peptides was calculated from the HPLC spectra using the AUC values. Data correspond to the 48 incubation. ${ }^{b}$ Data in brackets correspond to the 24 incubations. ${ }^{c}$ The ratio in case of compound 5 cannot be calculated because of the complexity of the HPLC spectrum (see Supporting Information Figure S6) 
i) In $0.2 \mathrm{M} \mathrm{NH}_{4} \mathrm{OAc}$ buffer at $\mathrm{pH} 5$ compounds $\mathbf{1}$, and $\mathbf{2}$ did not change at all while a small amount of decomposed products (1-4\%) were observed for 4, 5, 6 and 7 after 48 h. In contrast to the above compound $\mathbf{3}$ (HPLC chromatogram of pure compound is presented in Figure 1A), the tightest macrocycle composed of 15 atoms within the ring, decomposed even under acidic condition detected by HPLC. After $24 \mathrm{~h}$ the Asn:isoAsp:Asp ratio was about $85: 12: 3$ and the ratio of deamidated compounds increased with time (Table 2, Figure 1B).

A

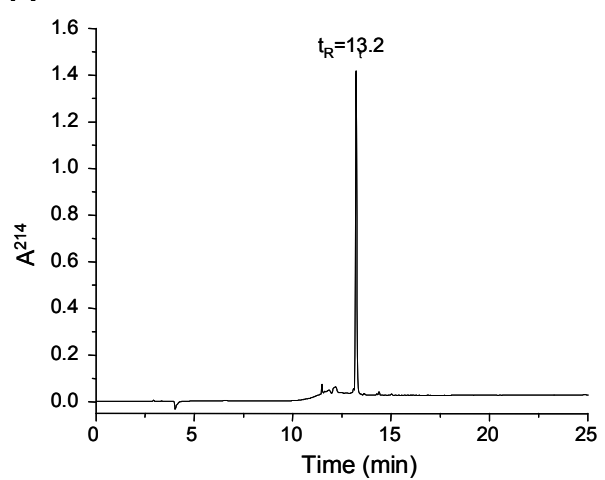

C

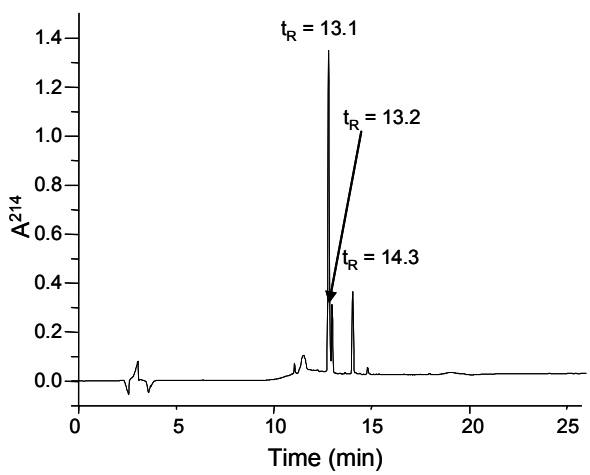

B

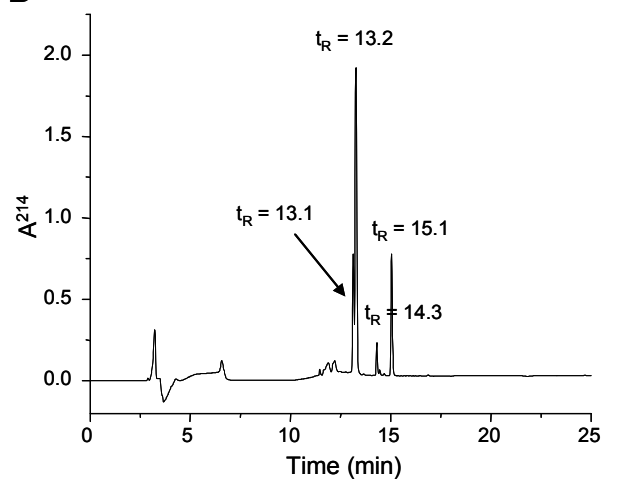

D

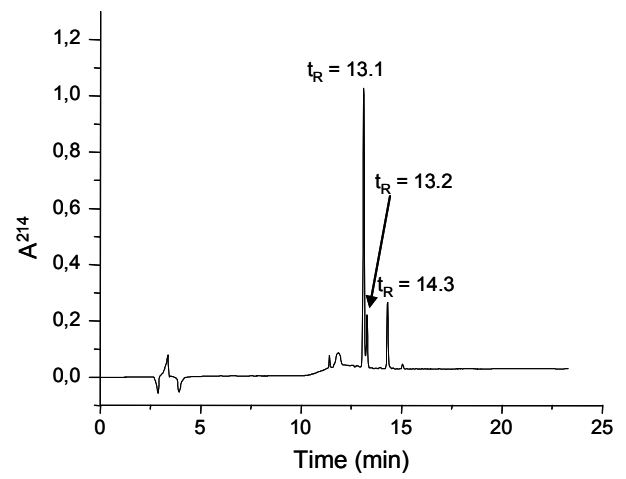

Figure 1. The chemo-stability assay reported for $\mathrm{c}\left[\mathrm{CH}_{2} \mathrm{CO}-\mathrm{NGRC}\right]-\mathrm{NH}_{2}$ (3): $\mathrm{HPLC}$ chromatograms after $48 \mathrm{~h}$ incubation at $25^{\circ} \mathrm{C}$ in water (A); in $0.2 \mathrm{M} \mathrm{NH}_{4} \mathrm{OAc}$ buffer (pH 5.0) (B); PBS solution (pH 7.4) (C); and 0.1 M Tris buffer (pH 8.1) (D). Retention times: 13.2 min corresponds to the intact $3 ; 13.1 \mathrm{~min}$ to $\mathrm{c}\left[\mathrm{CH}_{2} \mathrm{CO}-\right.$ isoDGRC $]-\mathrm{NH}_{2}$; and $14.3 \mathrm{~min}$ to $\mathrm{c}\left[\mathrm{CH}_{2} \mathrm{CO}-\mathrm{DGRC}\right]-\mathrm{NH}_{2}$. Retention time: $15.1 \mathrm{~min}$ in $0.2 \mathrm{M} \mathrm{NH}_{4} \mathrm{OAc}$ buffer corresponds to the Asu-derivative. 
ii) In PBS solution at pH 7.4 compounds $\mathbf{1}$ and $\mathbf{2}$ were fairly stable, and $\mathbf{6}$ a bit less stable. Interestingly, 5 with a Pro inside decomposed faster (25\% deamidated derivatives of Asn were observed after 48 h) while 4 and 7 deamidated even faster ( $>50 \%$ deamidated compounds after $48 \mathrm{~h}$ ). Under this condition compound 3 is the most sensitive: after $24 \mathrm{~h}$ about $64 \%$, while after $48 \mathrm{~h}$ about $85 \%$ of the starting material was rearranged (Figure $1 \mathrm{C}$ ). iii) In $0.1 \mathrm{M}$ Tris buffer at $\mathrm{pH} 8.1$ decomposition was more pronounced in general. While $\mathbf{1}$ is still stable, $\mathbf{2}$ is somewhat less stable than at conditions written before (vide supra) (the parent cyclic NGR peptide was $\sim 85 \%$ after $24 \mathrm{~h}$ and $\sim 71 \%$ after $48 \mathrm{~h}$ ). A similar deamidation rate was detected for 6 ( $73 \%$ unmodified 6 after 48 h) and a definitely higher one for $7(\sim 57 \%$ deamidated cyclic peptides after 48 h) only a little bit higher to what was observed in PBS. Deamidation of compound 4 in Tris is higher than it is in PBS buffer: $\sim 85 \%$ deamidated cyclic peptides after $48 \mathrm{~h}$, which was close to the decomposition of compound $3(\sim 87 \%)$ under this circumstances (Figure 1D). iv) In a cell culture medium (pH 7.3 and $37^{\circ} \mathrm{C}$ ) $\mathbf{1}$ is fairly stable for shorter time but substantially decomposed afterward (54\% of the parent cyclic peptide at $48 \mathrm{~h}$ ) in a non-linear manner (Figure 2). More than half of compound 2 was deamidated after $24 \mathrm{~h}$, and no intact molecule was found after $48 \mathrm{~h}$. Cyclic peptides with thioether linkage are also very sensitive in cell culture medium, 3-7 decomposed completely during $24 \mathrm{~h}$ incubation time.

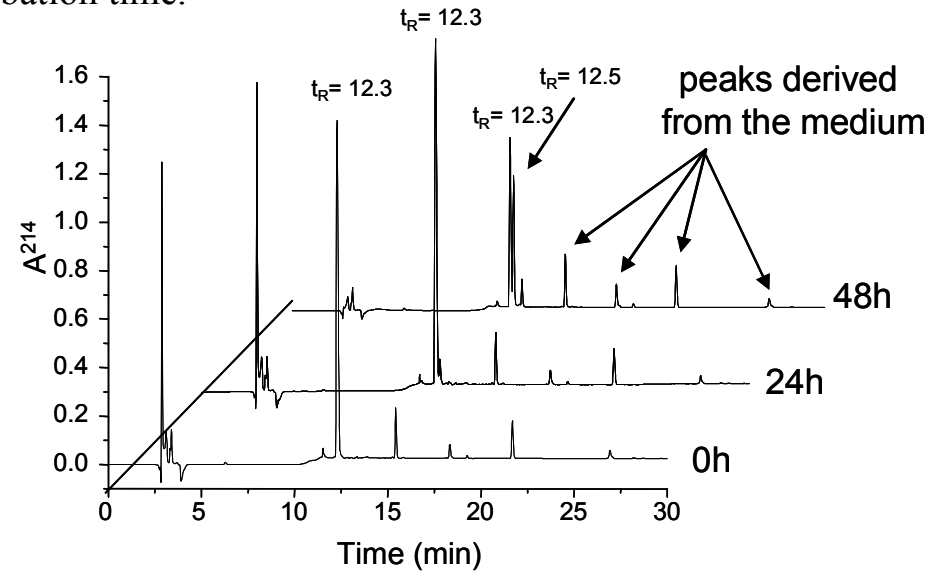

Figure 2. Time-dependent stability of c[KNGRE]-NH $\mathrm{NH}_{2}(\mathbf{1})$ in a cell culture medium at $37^{\circ} \mathrm{C}$ 


\section{Secondary structure by ECD spectra}

Cyclic pentapeptides often form different type of turns ( $\beta$ - and $\gamma$-turn). Considering the amino acid sequence, ring size and the presence of disulfide- or thioether bridges, the adoption of turns is very probable. The characteristic chiral contributions of different $\beta$-turns ${ }^{39}$ (C-, C'-, Btype ECD shape) and $\gamma$-turn ${ }^{40}$ to the ECD spectra has been studied in detail and reviewed and permit their discrimination by ECD spectroscopy. The unstructured conformation (U-type ECD curve) also can be distinguished by ECD.

ECD spectra were recorded in water and TFE. Spectra of $\mathbf{1}$ were significantly different from all the others (Figure 3). It has a broad positive band over $200 \mathrm{~nm}$ with maxima at $206 \mathrm{~nm}$ (3139.25) and at $218 \mathrm{~nm}(3062.53)$ in water and at $220 \mathrm{~nm}$ (1153.30) in TFE, respectively and a huge negative band below $200 \mathrm{~nm}(187 \mathrm{~nm}(-14906.70)$ in water and $195 \mathrm{~nm}(-8126.83)$ in TFE). Both ECD spectra are similar in TFE and water (similar characteristics but higher intensity in water), which looks like as a mixture of C'- and B-type pure ECD spectra. ${ }^{39}$

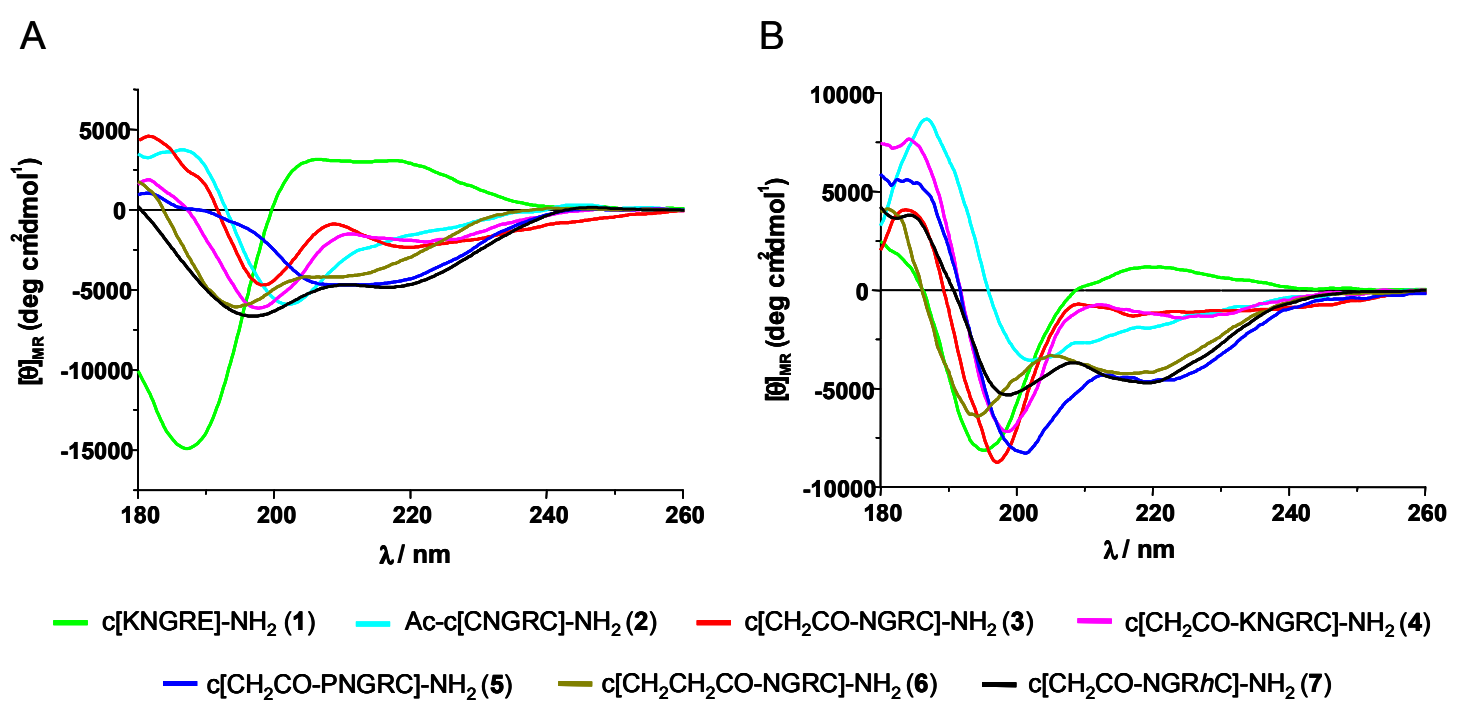

Figure 3. ECD spectra of cyclic NGR peptides (1-7) in water (A) and in TFE (B)

In TFE, cyclic compounds $\mathbf{3}$ and $\mathbf{4}$ show very similar ECD spectra marked by a positive band at $\sim 185 \mathrm{~nm}$, a negative band below $200 \mathrm{~nm}$ with a weak negative shoulder at $\sim 225 \mathrm{~nm}$ (a 
mixture of U- and C-type pure ECD curves). In water, the negative bands are more separated, their intensities are weaker and the intensity ratio of the longer-wavelength band and shortwavelength band is changed for both peptides. ECD spectral features of both $\mathbf{3}$ and $\mathbf{4}$ show elevated backbone flexibility, which is in line with their low chemo-stability. Compounds 2 and $\mathbf{5}$ show typical C-type spectra in TFE. In water, the ECD spectrum of $\mathbf{2}$ is as found in TFE suggesting its higher rigidity, while for $\mathbf{5}$ the solvent induced structural changes are a bit more significant: a very broad negative band has appeared in the $205-225 \mathrm{~nm}$ region.

The ECD spectra of compounds $\mathbf{6}$ and 7 in the structure-promoting solvent TFE show C-type features, marked by a positive $(\sim 185 \mathrm{~nm})$ and a negative band $(\sim 200 \mathrm{~nm})$ associated with a negative $n \pi *$ shoulder between $220-225 \mathrm{~nm}$. In water the spectrum of both peptides show two negative broad bands centered at $\sim 196 \mathrm{~nm}$ and $209 \mathrm{~nm}$ (6) or $218 \mathrm{~nm}$ (7). Although ECD spectra cannot reveal high resolution structural information by using $\mathrm{H}_{2} \mathrm{O}$ and TFE solutions, it is obvious that these cyclic NGR-peptides have different internal dynamics: some have more rigid backbone fold(s) as seen for $\mathbf{1}, \mathbf{2}, \mathbf{5}$, while others have perhaps more elevated internal dynamics (e.g. 3, 4).

\section{High-resolution ${ }^{1}$ H-NMR structures}

Distance restraints collected from ${ }^{1} \mathrm{H}-{ }^{1} \mathrm{H}$ ROESY spectra (for compounds 1-7 in total 106, 97, $87,122,107,79$ and 108, respectively) are higher than 20/residues, except for $\mathbf{6}$, although most of them are either intra-residual or sequential ones. Medium-range restraints, more indicative of the overall backbone fold(s), are less frequent. This signals that most of these cyclic peptides have considerable amount of internal dynamics. In principle, they can adopt several somewhat different backbone conformers in solution at $\mathrm{T}=288 \mathrm{~K}$ and $3<\mathrm{pH}<7$. No $\mathrm{pH}$ induced structural changes were detected neither by ECD nor NMR. However, due to the slower exchange rate of the NH resonances final NMR spectra were recorded at lower $\mathrm{pH}$. In 
conclusion, we have established the most prominent and characteristic backbone conformer(s) for each cyclic NGR-peptide. Additional minor conformers not resolved at the NMR timescale of motion could however be present to some extent making the conformational ensemble more colorful. The side chains, except those of $\mathbf{1}$, do not interact with each other or with backbone atoms in a specific manner and thus, they are conformationally diverse.

\section{Structural coherence of cyclic peptide 1-7}

Compound 1 (c[KNGRE]- $\mathrm{NH}_{2}$ ) has a well-defined backbone structure, but not very coherent: backbone and heavy atom RMSD values of $\mathbf{1}^{\text {major }}$ are around $0.31+/-0.23 \AA$ and $1.13+/-$ $0.65 \AA$, respectively. (For all data for all compounds see Supporting Information Table S1.) The minor conformer of $\mathbf{1}, \mathbf{1}^{\text {minor }}$, distinguished during structure calculations is similar to $\mathbf{1}^{\text {major }}$. Unlike for Arg, both $\varphi$ and $\psi$ torsion angles show larger fluctuation. In spite of its internal dynamics, less coherent structural ensemble, the main conformer, having a $\gamma$-turn at Gly, describes well the structural properties of $\mathbf{1}$ over time. Ac-c[CNGRC]- $\mathrm{NH}_{2}$, or $\mathbf{2}$ for short, also contains a $\gamma$-turn at Gly, with lower RMSDs $(0.16+/-0.20 \AA$ and $0.75+/-0.59 \AA$, respectively).

For compound 3, c[C $\left.\mathrm{CH}_{2} \mathrm{CO}-\mathrm{NGRC}\right]-\mathrm{NH}_{2}$, an atypical backbone conformer lacking common secondary structural elements was observed, with RMSDs $(0.36+/-0.23 \AA$ and $1.04+/-0.46$ $\AA$, respectively) slightly higher. Nevertheless, the increased internal dynamics (less coherent backbone fold) is in line with the lower chemo-stability of $\mathbf{3}$ (it decomposes during NMR measurements $40-50 \%$ after a few hours).

Structural properties of compounds $6\left(\mathrm{c}\left[\mathrm{CH}_{2} \mathrm{CH}_{2} \mathrm{CO}-\mathrm{NGRC}\right]-\mathrm{NH}_{2}\right)$ and $7\left(\mathrm{c}\left[\mathrm{CH}_{2} \mathrm{CO}-\right.\right.$ $\mathrm{NGR} h \mathrm{C}]-\mathrm{NH}_{2}$ ) are found similar. Although their $\varphi$ and $\psi$ torsional angles are slightly or for Asn even significantly different, their predominant backbone conformers contain $\gamma$ - and inverse $\gamma$-turns (at the -GR- subunits). Although 4, (c[CH $\left.\left.\mathrm{CH}_{2} \mathrm{CO}-\mathrm{KNGRC}\right]-\mathrm{NH}_{2}\right)$ and $\mathbf{5}$ 
(c $\left[\mathrm{CH}_{2} \mathrm{CO}-\mathrm{PNGRC}\right]-\mathrm{NH}_{2}$ ) have a bit larger ring size, closed by a thioether linkage, their RMSDs are also small: $0.09+/-0.10 \AA$ and $0.05+/-0.05 \AA$, respectively (Table S1), indicating coherent structural ensembles. However, their 3D-structures resemble to none of the conformers yet assigned. The latter cyclic NGR-peptides tend to form type-I $\beta$-turn instead of $\gamma$ - or inverse $\gamma$-turns assigned in 1-3, 6 and 7. In 5, two type-I $\beta$-turns were assigned at the positions Pro-Asn as well as Arg-Cys. In contrast, although 4 has almost the same amino acid sequence, it shows an atypical conformer in which only one distorted type-I $\beta$-turn was found for Lys-Asn. Even these side chains do not interact in any specific manner hence keeping their typical flexibility, these are a bit better defined in space: RMSD values $\sim 0.5 \AA$.

\section{A critical distance and angle enable succinimide ring formation for the -Asn-Gly- subunit}

For the least chemo-stable cyclic peptides, prone to form succinimide ring, both a specific Asn side chain conformation and a sterically preferred $\mathrm{NH}^{\mathrm{Gly}}$ orientation is needed. The distance between $\mathrm{N}^{\mathrm{Gly}}$ and $\mathrm{C}\left(\mathrm{O}^{\mathrm{Asn}-\mathrm{sc}}\right)$, or $d(\mathrm{~N}-\mathrm{C})$ for short(Figure 4$)$, could be a characteristic marker of the latter reaction in line with the most common mechanism described in the literature. $^{10}$

Macrocycle 3, c[C $\left.\mathrm{CH}_{2} \mathrm{CO}-\mathrm{NGRC}\right]-\mathrm{NH}_{2}$, of the smallest ring size (15 atoms) shows the highest ability to form succinimide ring via spontaneous deamidation. A short $d(\mathrm{~N}-\mathrm{C}), \sim 2.84 \AA$, with an $\mathrm{N}^{\mathrm{Gly}}-\mathrm{C} \gamma^{\mathrm{Asn}}-\mathrm{O} \delta^{\mathrm{Asn}}$ as Bürgi-Dunitz angle ${ }^{41} \sim 128^{\circ}$, facilities the succinimide ring formation and thus, 3 is the least chemo-stable cyclic NGR-peptide here (Table 3 and Figure 4). The rapid decomposition of $\mathbf{3}$ is enhanced as its $\mathrm{NH}^{\mathrm{Gly}}$ is oriented toward the side chain amid bond of Asn, but not H-bonded to the $\mathrm{CO}$ of Asn side chain (Figure 5B and 6A). Thus, due to a short $d(\mathrm{~N}-\mathrm{C})$ (less than the sum of van der Waals radii of the heavy atoms) and the obtuse 
Bürgi-Dunitz angle 3 forms isopeptide bond almost quantitatively ( $\sim 90 \%$ ) within $48 \mathrm{~h}$, in 0.1 M Tris buffer. (Note that in $\mathbf{3}$ no typical NH...CO type H-bond was assigned.)

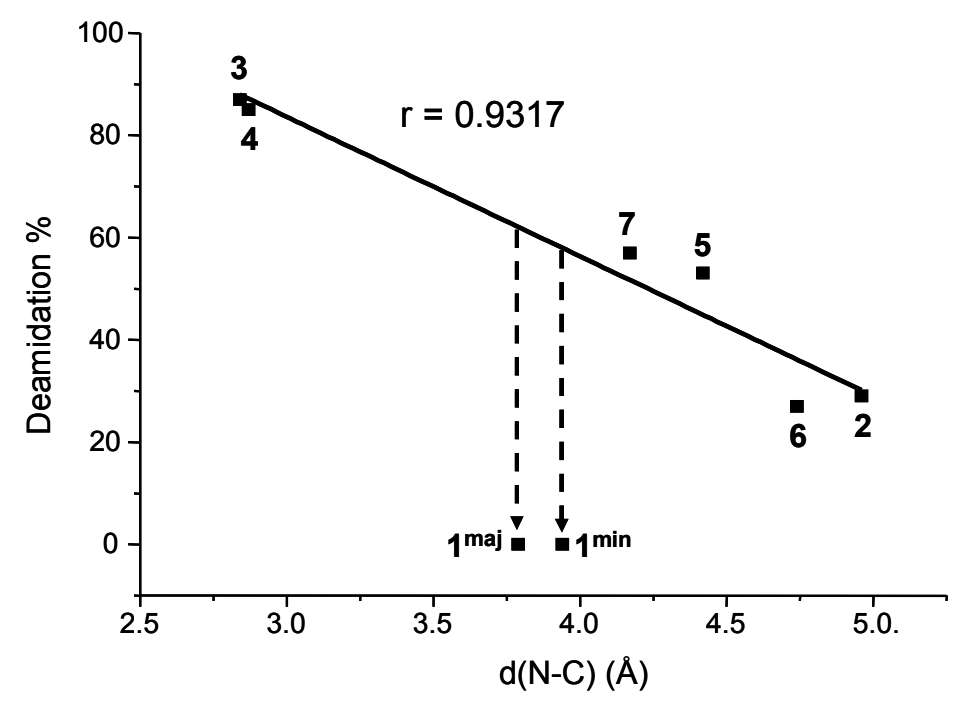

Figure 4. Correlation between the distance of $\mathrm{N}^{\mathrm{Gly}}$ and $\mathrm{C}\left(\mathrm{O}^{\mathrm{Asn}-\mathrm{sc}}\right)$ and deamidation rate 100x $[(i s o \mathrm{DGR}+\mathrm{DGR}$ peptides/NGR $+i s o \mathrm{DGR}+\mathrm{DGR}$ peptides $)]$ of cyclic NGR-peptides 1-7 in Tris buffer (pH 8.1) after $48 \mathrm{~h}$.

Compound 4, $\mathrm{c}\left[\mathrm{CH}_{2} \mathrm{CO}-\mathrm{KNGRC}\right]-\mathrm{NH}_{2}$, has similar backbone and side chain orientations as found in 3, especially in its -Asn-Gly-Arg- subunit: $-\delta_{\mathrm{D}^{-}} \delta_{\mathrm{L}^{-}} \delta_{\mathrm{L}^{-}}($Table 3$){ }^{42}$ The less optimal Bürgi-Dunitz angle $\left(\sim 90^{\circ}\right)$ but the relatively short $d(\mathrm{~N}-\mathrm{C})(2.87 \AA)$ predicts an easy succinimide ring formation for 4 . Once again, no characteristic H-bond stabilizes macrocycle 4. In line with the HPLC isoAsp and Asp formation (Table 2) 4 self-decomposes within $48 \mathrm{~h}$ in Tris buffer (Figure 4).

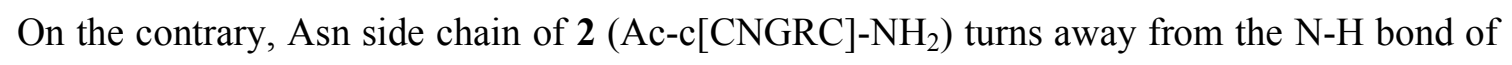
Gly (Figure $6 \mathrm{~B}$ ) and disables $\mathrm{N}^{\mathrm{Gly}}$ to form easily a succinimide ring: $d(\mathrm{~N}-\mathrm{C})$ is large $(4.96 \AA)$, while Bürgi-Dunitz angle is $\sim 117^{\circ}$. In addition, by adopting an inverse $\gamma$-turn $\left(\gamma_{\mathrm{L})}\right.$ (Table 3) centered by Asn forms a strong backbone H-bond between the NH group of Gly and the carbonyl oxygen of cysteine in position 1 (1.86 $\AA$ ), reducing the chance of Asn isomerization. 
In conclusion, based on its structural properties revealed by CD and NMR 2 could be highly resistant against succinimide ring formation and thus, against decomposition. Indeed, $\mathbf{2}$ is a very chemo-stable peptide (Table 2 and Figure 4): even after $48 \mathrm{~h}$ in Tris buffer the ratio of deamidation is lower than $30 \%$. The -Asn-Gly- moiety of $\mathbf{6}$ forms two $\gamma$-turn structures: $-\gamma_{L^{-}}$ $\gamma_{D^{-}}$(Table 3) with two robust intramolecular H-bonds $(\mathrm{R}(\mathrm{NH}) \cdots \mathrm{N}(\mathrm{CO}) \quad 1.63 \AA$ and $\mathrm{G}(\mathrm{NH}) \cdots \operatorname{Prop}(\mathrm{CO}) 1.82 \AA$ ) fixing the backbone of the -NGR- subunit (Figure 5C). Once again the side chain of Asn is turned away, resulting in larger $d(\mathrm{~N}-\mathrm{C})(4.74 \AA)$ and BürgiDunitz angle $\sim 145^{\circ}$, forecasting higher chemical stability. Compound 6 was found both by HPLC and NMR measurements reluctant to isomerize: conversion is $\sim 27 \%$ after $48 \mathrm{~h}$ in Tris buffer.

A
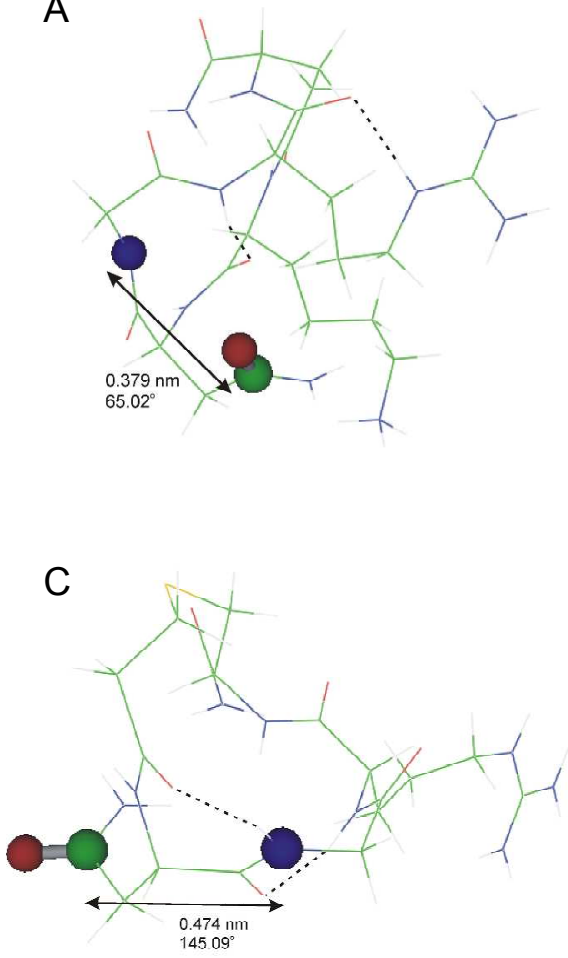

B
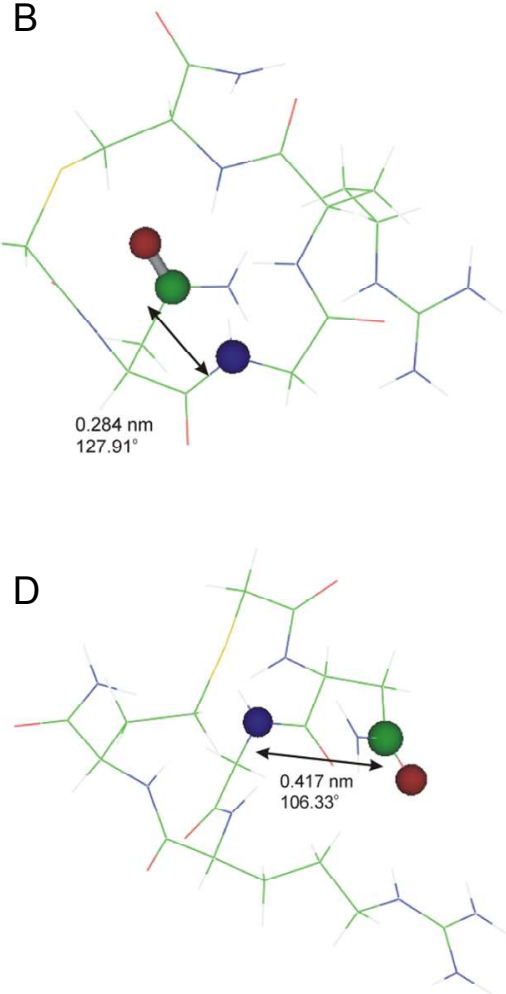

Figure 5. Structures of cyclic NGR peptides $\mathbf{1}^{\text {major }}$ (A), 3 (B), 6 (C) and 7 (D) presenting the $d(\mathrm{~N}-\mathrm{C})$ and Bürgi-Dunitz angle between $\mathrm{N}^{\mathrm{Gly}}$ (blue sphere) and $\mathrm{CO}^{\mathrm{Asn}-\mathrm{sc}}(\mathrm{C}$ is green sphere and $\mathrm{O}$ is red sphere)as well as the H-bonds (dashed lines) 
Compound $7\left(\mathrm{c}\left[\mathrm{CH}_{2} \mathrm{CO}-\mathrm{NGR} h \mathrm{C}\right]-\mathrm{NH}_{2}\right)$ has identical ring size as 6 (16 atoms) with -S- at a shifted position. Although the -Gly-Arg- subunit adopts two distorted $\gamma$-turns, $-\gamma_{D^{-}} \gamma_{L^{-}}$(Table 3) no H-bond stabilizes the backbone of this macrocycle, providing an elevated internal dynamics to it (Figure 5D). The side chain of Asn is still turned away $(d(\mathrm{~N}-\mathrm{C})=4.17 \AA$ and Bürgi-Dunitz angle $\sim 106^{\circ}$ ), but the larger backbone flexibility of 7 makes it more ready for isopeptide formation (conversion close to $60 \%$ after $48 \mathrm{~h}$ in Tris buffer).

Similarly in $\mathbf{5}\left(\mathrm{c}\left[\mathrm{CH}_{2} \mathrm{CO}-\mathrm{PNGRC}\right]-\mathrm{NH}_{2}\right)$ no $\mathrm{H}$-bond(s) stabilizes the backbone structure of the macrocycle, although it encompasses a distorted $\beta$-II'-turn structure: $-\delta_{L^{-}} \alpha_{D^{-}}$(Table 3 ). Not only $d(\mathrm{~N}-\mathrm{C})(4.42 \AA)$ is longer and Bürgi-Dunitz angle $\sim 155^{\circ}$ is too large, but also it has an $\mathrm{H}$-bond between the $\mathrm{NH}^{\mathrm{Asn}-\mathrm{sc}}$ and the $\mathrm{CO}^{\mathrm{Asn}-\mathrm{bb}}: d(\mathrm{H} \ldots \mathrm{O}) \sim 1.8 \AA$. These structural features make 5 a rather stable macromolecule of lower flexibility and thus, it decomposes slower than 3, 4 and 7, but faster than 2 and 6 (Figure 4).

Table 3. Backbone conformers of the X-NGR-Y-peptides

\begin{tabular}{|l|ccccc|c|c|}
\hline \multicolumn{1}{c|}{ Compounds } & $\mathbf{X}$ & $\mathbf{N}$ & $\mathbf{G}$ & $\mathbf{R}$ & $\mathbf{Y}$ & $\boldsymbol{d}(\mathbf{N}-\mathbf{C})$ & "BD angle” \\
$\mathrm{c}[\mathrm{KNGRE}]-\mathrm{NH}_{2}$ (1) major conf. & $\beta \mathrm{L}$ & $\alpha \mathrm{D}$ & $\gamma \mathrm{D}$ & $\gamma \mathrm{L}$ & $\delta \mathrm{D}$ & $3.79 \AA$ & $65.02^{\circ}$ \\
$\mathrm{c}[\mathrm{KNGRE}]-\mathrm{NH}_{2}(\mathbf{1})$ minor conf. & $\varepsilon \mathrm{L}$ & $\alpha \mathrm{D}$ & $\gamma \mathrm{D}$ & $\alpha \mathrm{L}$ & $\alpha \mathrm{L}$ & $3.94 \AA$ & $78.65^{\circ}$ \\
$\mathrm{Ac}-\mathrm{c}[\mathrm{CNGRC}]-\mathrm{NH}_{2}(\mathbf{2})$ & $\varepsilon \mathrm{L}$ & $\gamma \mathrm{L}$ & $\gamma \mathrm{D}$ & $\delta \mathrm{L}$ & $\gamma \mathrm{L}$ & $4.96 \AA$ & $117.21^{\circ}$ \\
$\mathrm{c}\left[\mathrm{CH}_{2} \mathrm{CO}-\mathrm{NGRC}\right]-\mathrm{NH}_{2}(\mathbf{3})$ & - & $\delta \mathrm{D}$ & $\delta \mathrm{L}$ & $\delta \mathrm{L}$ & $\alpha \mathrm{L}$ & $2.84 \AA$ & $127.91^{\circ}$ \\
$\mathrm{c}\left[\mathrm{CH}_{2} \mathrm{CO}-\mathrm{KNGRC}\right]-\mathrm{NH}_{2}(\mathbf{4})$ & $\alpha \mathrm{L}$ & $\delta \mathrm{D}$ & $\delta \mathrm{L}$ & $\delta \mathrm{L}$ & $\delta \mathrm{L}$ & $2.87 \AA$ & $89.31^{\circ}$ \\
$\mathrm{c}\left[\mathrm{CH}_{2} \mathrm{CO}-\mathrm{PNGRC}\right]-\mathrm{NH}_{2}(\mathbf{5})$ & $\alpha \mathrm{L}$ & $\delta \mathrm{L}$ & $\alpha \mathrm{D}$ & $\alpha \mathrm{L}$ & $\alpha \mathrm{L}$ & $4.42 \AA$ & $155.22^{\circ}$ \\
$\mathrm{c}\left[\mathrm{CH}_{2} \mathrm{CH} \mathrm{CO}_{2} \mathrm{NGRC}\right]-\mathrm{NH}_{2}(\mathbf{6})$ & - & $\gamma \mathrm{L}$ & $\gamma \mathrm{D}$ & $\alpha \mathrm{L}$ & $\alpha \mathrm{D}$ & $4.74 \AA$ & $145.09^{\circ}$ \\
$\mathrm{c}\left[\mathrm{CH}_{2} \mathrm{CO}-\mathrm{NGRhC}\right]-\mathrm{NH}_{2}(\mathbf{7})$ & - & $\delta \mathrm{L}$ & $\gamma \mathrm{D}$ & $\gamma \mathrm{L}$ & $\delta \mathrm{D}$ & $4.17 \AA$ & $106.33^{\circ}$ \\
\hline
\end{tabular}


Representative 3D- local folds of the cyclic NGR-peptides depicted by one of the 9 typical backbone conformers / amino acid residue, namely $\alpha L, \beta L, \gamma L, \delta L, \varepsilon L, \alpha D, \gamma D, \delta D$, and $\varepsilon D$ as introduced earlier. " $B D$-angle" angle of $\left(N^{G l y}-C \gamma^{A s n}-O \gamma^{A s n}\right)$

Compound 1 (c[KNGRE]-NH ) seems to be the only outlier, as

i) $\mathbf{1}$ presents two somewhat different conformers, called as $\mathbf{1}^{\text {major }}$ and $\mathbf{1}^{\text {minor }}$ and

ii) both forms of 1 (major and minor) have $d(\mathrm{~N}-\mathrm{C})$ of intermediate length: $3.79 \AA$ and $3.94 \AA$, with a smaller value of Bürgi-Dunitz angles $\sim 65^{\circ}$ and $\sim 79^{\circ}$, respectively.

Therefore, one would expect $\mathbf{1}$ to be as chemo-stable as 7. By interpolating the recent chemical stability data as function of $d(\mathrm{~N}-\mathrm{C})$ (Figure 4$)$ the isopeptide bond formation of $\mathbf{1}$ is forecasted to be $\sim 65 \%$ (in Tris buffer after $48 \mathrm{~h}$ ). However, 1 was found by far the most chemo-stable macrocycle: no decomposition is observed (conversion $<1 \%$ after $48 \mathrm{~h}$ in Tris buffer). One may wonder what structural feature stabilizes $\mathbf{1}$ and prevents its form decomposition. A thorough structural analysis reveals and explains the extreme chemostability of $\mathbf{1}$, as follows:

i) both forms of $\mathbf{1}$ (minor and major) incorporates a type-I' $\beta$-turn $\left(-\alpha_{D^{-}} \gamma_{D^{-}}\right)$at its -AsnGly- subunit (Table 3), having Gly in it as a $\gamma$-turn.

ii) In $\mathbf{1}^{\text {major }}$ a strong backbone interaction $d\left(\mathrm{NH}^{\mathrm{Arg}} \ldots \mathrm{CO}^{\mathrm{Lys}}\right) \sim 1.6 \AA$ and a robust backbone-side chain H-bond, $d\left(\mathrm{NH}^{\mathrm{Arg}-\mathrm{sc}} \ldots \mathrm{CO}^{\mathrm{Arg}}\right) \sim 1.9 \AA$, lock the fold in such a way, that the $\mathrm{N}^{\mathrm{Gly}}$ cannot attack as a nucleophile from the back-side of the molecule (Figure 5A).

iii) In $\mathbf{1}^{\text {minor }}$ three backbone - side chain H-bonds $\left(d\left(\mathrm{NH}_{2}{ }^{\mathrm{Glu}} \ldots \mathrm{CO}^{\mathrm{Glu}-\mathrm{sc}}\right) \sim 1.9 \AA\right.$, $d\left(\mathrm{NH}^{\mathrm{Arg}} \ldots \mathrm{CO}^{\mathrm{Asn}-\mathrm{sc}}\right) \sim 2.5 \AA$ and $d\left(\mathrm{NH}^{\mathrm{Gly}} \ldots \mathrm{CO}^{\mathrm{Glu}-\mathrm{sc}}\right) \sim 2.4 \AA$ as well as a robust backbone-backbone $\mathrm{H}$-bond, $d\left(\mathrm{NH}^{\mathrm{Glu}-\mathrm{sc}} \ldots \mathrm{CO}^{\mathrm{Lys}}\right) \sim 2.6 \AA$ lock the fold and disables $\mathrm{N}^{\mathrm{Gly}}$ to attack as a nucleophile.

Thus, in both forms of $\mathbf{1}$ complex H-bond networks stabilize the 3D-fold in which the Asn is turned away from $\mathrm{N}^{\mathrm{Gly}}$ and thus, disfavors the succinimide ring formation. In 
conclusion, in a flexible backbone fold, if $d(\mathrm{~N}-\mathrm{C})$ is short and Bürgi-Dunitz is slightly obtuse $\left(\sim 107^{\circ}\right)$, then isomerization will take place easily. However, the latter thumb rule holds only, if an H-bond(s) do not lock the macrocycle in such a fold where either $\mathrm{N}^{\mathrm{Gly}}$ cannot be a nucleophile and/or in the vicinity of $\mathrm{CO}^{\mathrm{Asn}-\mathrm{sc}}$.

A

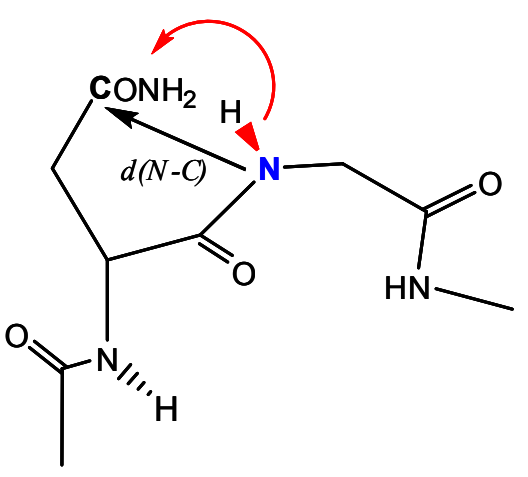

B

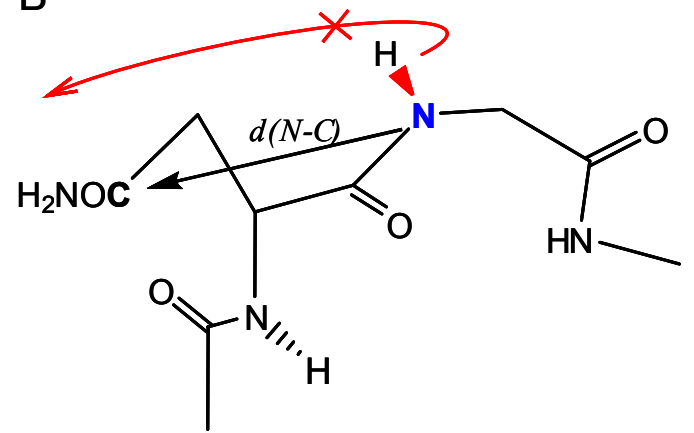

Figure 6. A) Rapidly decomposing molecules (3 and 4), both of low chemo-stability, have Asn side chain oriented toward $\mathrm{NH}^{\mathrm{Gly}}$ faciliting succinimide ring formation. B) Chemo-stable compounds (e.g. 2, 6) have Asn side chains oppositely oriented away from $\mathrm{NH}^{\mathrm{Gly}}$ making succinimide ring formation difficult. If B-type structures are further stabilized by H-bonds, cyclopeptides get more rigid and succinimide ring formation becomes impossible as seen for $\mathbf{1}^{\text {major }}$ and $\mathbf{1}^{\text {minor }}$.

\section{Cyclic NGR-peptides effect on cell adhesion}

Formation of isoAsp derivatives from -Asn-Gly- containing fragments is expected to be frequent both in vitro and in vivo systems. According to the literature data, many of the studied cyclic isoDGR peptide (e.g. c[CisoDGRC]GVRY (isoDGR-2C)) show high affinity to $\alpha_{v} \beta_{3}$ RGD binding integrin receptor in nanomolar concentration. ${ }^{43}$ However, the receptor recognition of isoDGR peptides highly depends on their structure. ${ }^{13,44}$ Our objective was to evaluate the $3 \mathrm{D}$ structure, the chemo-stability as well as the in vitro interaction of these peptide models. For such study, cell adhesion was monitored as one of the most 
characteristics integrin dependent property of metastatic tumorigenesis. The potential effect on cell adhesion was measured on A2058 melanoma cell line in impedance-based functional assay for the cyclic NGR-peptide coated surfaces. A2058 cells were selected for this study because it was indicated previously that the chemotaxis, haptotaxis, motility and migration of A2058 cells are mediated mainly by the highly expressed $\alpha_{\mathrm{v}} \beta_{3}$ receptor on it. ${ }^{45}$

Rearrangement of the studied cyclic NGR-peptides to isoAsp derivatives takes time, as shown above. This time-dependent formation of isoAsp derivatives having integrin receptor binding propensities may result in development of effect on cell adhesion in time. In contrast to NGRpeptides, RGD and isoDGR peptides that recognize RGD binding integrin receptors can influence the cell adhesion in a short time period. Therefore, $c[$ RGDfV] peptide that have efficient $\alpha_{v} \beta_{3}$ integrin binding property was considered as a positive control. To prove our hypothesis that the isoAsp derivatives have integrin binding activity and therefore resulting in increased adhesion effect, the most rapidly forming isoAsp derivative (c[ $\mathrm{CH}_{2} \mathrm{CO}$-isoDGRC]$\mathrm{NH}_{2}$; derived from compound 3) was also screened. The xCELLigence SP system (Roche Applied Science, Indianapolis, IN, USA) used for cell adhesion measurements allowed us to monitor A2058 cell line in a real time manner (sampling of data in every $20 \mathrm{sec}$ ) for 25 hours. The $\mathrm{c}[\mathrm{RGDfV}]$ peptide developed a rapid (in less than $5 \mathrm{~h}$ ) concentration dependent adhesion inducing effect at $10^{-7}-10^{-6} \mathrm{M}$ concentrations while its effect decreased in long term (after 10 h). In case of $\mathrm{c}\left[\mathrm{CH}_{2} \mathrm{CO}-i\right.$ soDGRC $]-\mathrm{NH}_{2}$, a similar concentration and time-dependent adhesion inducer effect was shown to the $c[R G D f V]$ in the $10^{-7}-10^{-6} \mathrm{M}$ range (Figure 7). The adhesion of A2058 cells incubated with $10^{-6} \mathrm{M} c\left[\mathrm{CH}_{2} \mathrm{CO}-i s o\right.$ DGRC $]-\mathrm{NH}_{2}$ reached the maximum level within $5 \mathrm{~h}$ and a slight, gradual decline could be detected after $10 \mathrm{~h}$ (Figure 7). In contrast, $\mathrm{c}\left[\mathrm{CH}_{2} \mathrm{CO}-\mathrm{NGRC}\right]-\mathrm{NH}_{2}(3)$ enhanced continuously the cell adhesion after $5 \mathrm{~h}$ incubation time. In $10^{-7} \mathrm{M}$ of compound $\mathbf{3}$, a significant gradual increase in the cell adhesion was elicited with long-term characteristics (Figure 7). The comparison of the two cyclic peptides $\mathbf{1}$ and $\mathbf{2}$ 

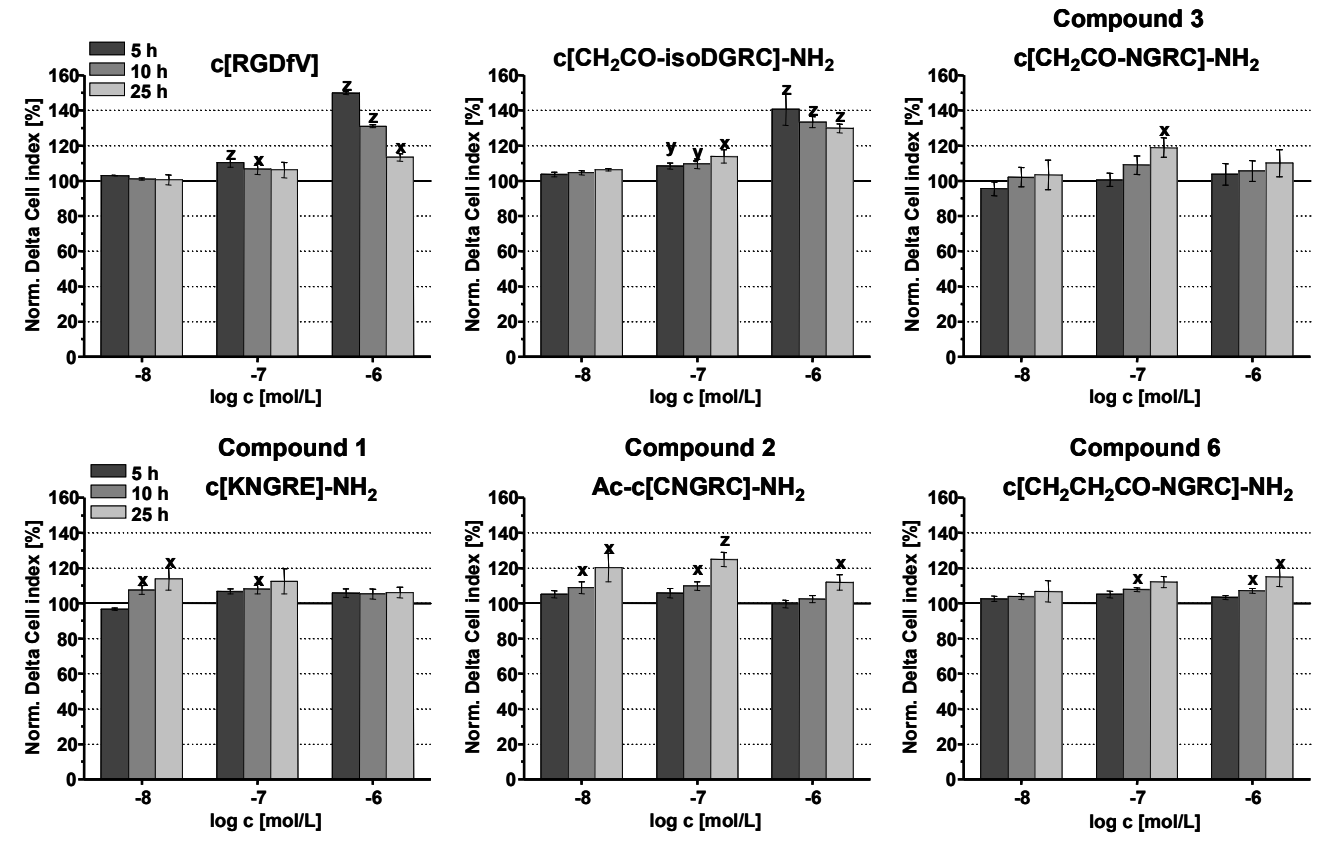

Figure 7. Time-dependent cell adhesion of A2058 melanoma cell line induced by c[RGDfV], $\mathrm{c}\left[\mathrm{CH}_{2} \mathrm{CO}-i s o\right.$ DGRC $]-\mathrm{NH}_{2}$ and cyclic NGR-peptides (compound 3, 1, 2 and 6). The Norm. Delta CI (Normalized Delta Cell index) values were calculated at individual time points $(5,10$ and $25 \mathrm{~h}$ ), and were normalized to the control (control=100\%). The level of significance is shown as follows: $\mathrm{x}-\mathrm{p}<0.05 ; \mathrm{y}-\mathrm{p}<0.01 ; \mathrm{z}-\mathrm{p}<0.001$.

Compound 2 (Ac-c[CNGRC]- $\mathrm{NH}_{2}$ ) with lower chemo-stability enhanced continuously the cell adhesion during the incubation time $(5-25 \mathrm{~h})$, especially in the $10^{-8}-10^{-7} \mathrm{M}$ concentration range while in case of compound $\mathbf{1}\left(\mathrm{c}[\mathrm{KNGRE}]-\mathrm{NH}_{2}\right)$ that was fairly stable even in cell culture medium at $37^{\circ} \mathrm{C}$, such type of effect was moderate $\left(10^{-8}-10^{-7} \mathrm{M}\right)$ or insignificant $\left(10^{-6}\right.$ M). An adhesion inducer effect could also be detected for compound $6\left(\mathrm{c}^{2} \mathrm{CH}_{2} \mathrm{CH}_{2} \mathrm{CO}-\right.$ $\mathrm{NGRC}]-\mathrm{NH}_{2}$ at $10^{-7}-10^{-6} \mathrm{M}$ and this character became more pronounced by the later time 
points (Figure 7). However, the volume of its positive character was less than that of compound 3. The other cyclic NGR-peptides containing thioether linkage (compound $\mathbf{4}, \mathbf{5}$ and 7) proved to be neutral during the whole period of measurement in the entire concentration range (data not shown).

\section{DISCUSSION}

The application of the parent NGR-peptides or their drug conjugates might have importance in tumor therapy. However, the easy deamidation of the NGR-peptides, resulting in both isoAsp- and Asp-derivatives, indicates the difficulties in their synthesis and biological experiments. Therefore, their stability studies under appropriate circumstances are necessary. We demonstrated previously that cyclic peptides with thioether linkage in the ring are more stable under both chemical and biological conditions than those containing either amide-or disulfide-bonds. ${ }^{37}$ Therefore, five new cyclic NGR-peptides, all ringed with a thioether bond were prepared to select appropriate constructs for tumor drug targeting studies. Cyclic peptides of different ring sizes $(15<n<18$ atoms) were designed based on previous studies. ${ }^{13,19,20}$ The smallest ring size $(n=15)$ is that of $\mathbf{3}, \mathrm{c}\left[\mathrm{CH}_{2} \mathrm{CO}-\mathrm{NGRC}\right]-\mathrm{NH}_{2}$, while its elongated derivatives $4, \mathrm{c}\left[\mathrm{CH}_{2} \mathrm{CO}-\mathrm{KNGRC}\right]-\mathrm{NH}_{2}$ and $\mathbf{5}, \mathrm{c}\left[\mathrm{CH}_{2} \mathrm{CO}-\mathrm{PNGRC}\right]-\mathrm{NH}_{2}$ have the largest ring size $(n=18)$. The synthesis of both $\mathbf{6}, \mathrm{c}\left[\mathrm{CH}_{2} \mathrm{CH}_{2} \mathrm{CO}-\mathrm{NGRC}\right]-\mathrm{NH}_{2}$ and 7 , $\mathrm{c}\left[\mathrm{CH}_{2} \mathrm{CO}-\mathrm{NGR} h \mathrm{C}\right]-\mathrm{NH}_{2}(n=16)$ is justified by their easy synthetic routes. (Up to now, no cyclic NGR-peptides of 17-membered ring size with thioether linkage have yet been prepared.) In addition, two reference cyclic NGR-peptides with amide or disulfide bonds of 17-atoms in the ring (c[KNGRE]-NH $\mathrm{NH}_{2}$ (1) and $\mathrm{Ac}-\mathrm{c}[\mathrm{CNGRC}]-\mathrm{NH}_{2}(\mathbf{2})$ ) were prepared that were successfully applied previously for drug targeting. ${ }^{33,34}$ An alternative synthetic route for $\mathbf{1}$ is proposed here. ${ }^{33}$ Synthetic conditions used for disulfide bond formation as well as their 
yield were studied for $\mathbf{2}$ and found that alkaline conditions for disulfide bond formation should be avoided.

As deamidation of NGR-peptides via succinimide ring closure, followed by hydrolysis to make both Asp and isoAsp derivatives is well known, the chemo-stability of selected cyclic NGR-peptides is studied here. Conditions were selected based on the applied synthetic routes for cyclization, for drug conjugation, or in in vitro biological experiments. Chemo-stability of these cyclic-peptides with thioether linkage was compared to the two reference compounds. As found in the literature, the elevation of the $\mathrm{pH}$ and/or temperature, as well as the use of buffers increases decomposition of any cyclic NGR-peptides. However, significant differences were found in succinimide ring formation rate for the present compounds, namely $\mathbf{1}>\mathbf{6} \sim \mathbf{2}>\mathbf{5}>\mathbf{7}>\mathbf{4}>\mathbf{3}$ order was established. It is worth mentioning, that after isomerization the ratio of Asp/isoAsp depends on compounds. For c $\left[\mathrm{CH}_{2} \mathrm{CO}-\mathrm{PNGRC}\right]-\mathrm{NH}_{2}$ the Asp derivative dominates the mixture.

We supposed that differences in chemo-stability have a structural and internal mobility "background". Verification of the latter concept was done both by ECD and NMR measurements. While ECD gives information on the overall folds of these NGR-peptides, NMR provides the same but at atomic details. The present conclusions are as follows: $i$ ) the spatial proximity of Asn side chain to $\mathrm{N}^{\mathrm{Gly}}$ facilitates succinimide ring formation. ii) In contrast to it, if $\mathrm{N}^{\mathrm{Gly}}$ takes part of an $\mathrm{H}$-bond, decomposition via succinimide ring formation is difficult or impossible. From the NMR data analysis, we conclude that $d(\mathrm{~N}-\mathrm{C})$, the distance of $\mathrm{N}^{\mathrm{Gly}}$ and $\mathrm{C} \gamma^{\mathrm{Asn}-\mathrm{sc}}$ atoms is a relevant measures of reactivity rate, significant correlation was established (Figure 4). iii) However, if Asn side chain is pointing away from $\mathrm{N}^{\mathrm{Gly}}$, and the molecular fold is locked by H-bonds in the latter conformation, chemo-stability will be high, NGR will hardly decompose as seen for $\mathbf{1} \mathrm{c}[\mathrm{KNGRE}]-\mathrm{NH}_{2}$. In PBS, the latter correlation is less pronounced but still significant. 
The tumor selectivity and consequently the drug delivery ability of cyclic NGR peptides arise from two factors: as found in the literature, (i) NGR-peptides bind to CD13 receptor overexpressing on angiogenic endothelium, while (ii) the deamidated isoDGR derivatives similarly to RGD peptides - bind to the RGD-specific integrin receptors (Figure 8). The binding efficacy to receptors cannot be characterized properly in the absence of radio- or fluorescent-labeled derivatives. Furthermore, there are only few cell types (HUVEC and HT1080 fibrosarcoma) that are available for determining CD13 binding of peptides. ${ }^{46}$ Therefore, in a preliminary study the possible binding of deamidated compounds to integrin receptors was performed by using an indirect method. As integrin receptors influence cell adhesion, the binding of isoDGR peptides to these receptors might change their adhesive propensity. The results showed that in case of the control cyclic peptides such as (c[RGDfV] and the integrin binding compound 3 derived $\mathrm{c}\left[\mathrm{CH}_{2} \mathrm{CO}\right.$-isoDGRC]- $\mathrm{NH}_{2}$ reached the maximum effect on cell adhesion in a short time while some of the cyclic NGR-peptides (compounds $\mathbf{1}, \mathbf{2}, \mathbf{3}$, and $\mathbf{6}$ ) the cell adhesion was increased during the period of experiments (up to $25 \mathrm{~h}$ ). The increase of time-dependent cell adhesion can be explained by deamidation progress of cyclic NGRpeptides resulting in isoAsp derivatives. In case of compounds 4 and 7, the absence of the effect on cell adhesion might derive from the lack of binding to integrin receptors. Deamidation of Pro-containing compound 5 results in rather Asp and not isoAsp derivative that does not bind to integrin receptors according to the literature.

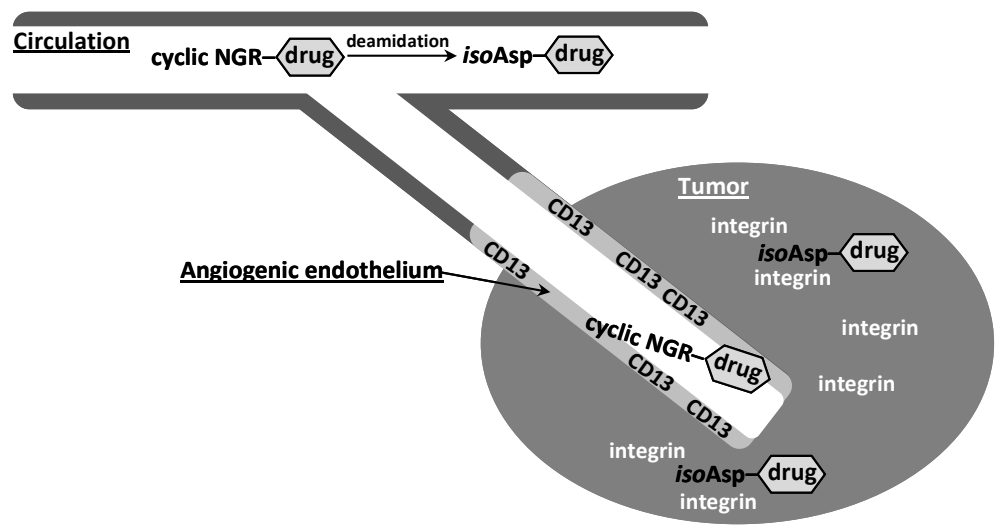


Figure 8. Schematic mode of action of a cyclic NGR-peptide in targeted drug delivery of tumors

In conclusion, while chemo-stable cyclic NGR-peptides could be used for drug targeting via CD13 receptors, compounds easily decomposing to form isoAsp derivatives might be applied for a dual targeting strategy. Both CD13 and RGD type integrin receptors could be reached by these molecules during targeted tumor therapy (Figure 8). To decide whether this dual targeting has any advantages over the application of NGR or RGD peptides alone or in a mixture needs further studies. For this purpose, the present cyclic NGR-peptides with thioether linkage are promising candidates to develop drug conjugates for targeted tumor therapy.

\section{MATERIALS AND METHODS}

All amino acid derivatives and Rink-Amide MBHA resin were purchased from Iris Biotech GmBH (Marktredwitz, Germany). Chemicals for the syntheses, purification and analyses (acetic anhydride $\left(\mathrm{Ac}_{2} \mathrm{O}\right), \quad p$-cresol, 1,8-diazabicyclo[5.4.0]undec-7-ene (DBU), N,N'diisopropylcarbodiimide (DIC), $N$-diisopropylethylamine (DIEA), hydrogen fluoride (HF), 1hydroxybenzotriazole (HOBt), piperidine, trifluoroacetic acid (TFA), 2,2,2-trifluoroetanol (TFE), triisopropylsilane (TIS), and tallium trifluoroacetate $\left(\mathrm{Tl}(\mathrm{tfa})_{3}\right)$ were obtained from Sigma-Aldrich Kft. (Budapest, Hungary), while the solvents (dichloromethane (DCM), N,Ndimethylformamide (DMF), acetonitrile (MeCN), ethanol and diethyl ether) were purchased from Molar Chemicals (Budapest, Hungary). All reagents and solvents were of analytical grade or highest available purity.

\section{Synthesis of c[KNGRE]-NH 2 cyclic peptid (1) with amide bond}


Linear semi-protected H-Lys(ClZ)-Asn-Gly-Arg-Glu-NH $\mathrm{NH}_{2}$ was prepared by $\mathrm{Fmoc} /{ }^{t} \mathrm{Bu}$ strategy on Rink-Amide MBHA resin $(0.5 \mathrm{~g}, 0.64 \mathrm{mmol} / \mathrm{g}$ capacity) according to the protocol described in the Supporting Information. Standard Fmoc-amino acid derivatives were used for the synthesis expect Boc-Lys(ClZ)-OH that was attached to the N-terminus of the peptide. The semi-protected peptide was cleaved from the resin using a mixture of $95 \%$ TFA, $2.5 \%$ TIS and $2.5 \%$ water $(\mathrm{v} / \mathrm{v} / \mathrm{v})$ for $2.5 \mathrm{~h}$ at room temperature and then precipitated with ice-cold diethyl ether, washed three times with diethyl ether and dissolved in $100 \%$ acetic acid prior to freeze drying. The crude product was purified by semi-preparative RP-HPLC followed by counter ion exchange of tfa to chloride using pyridinium hydrochloride prior cyclization. The semi-protected linear peptide was cyclized in DMF at $0.2 \mathrm{mg} / \mathrm{mL}$ peptide concentration in the presence of $\mathrm{BOP} / \mathrm{HOBt} / \mathrm{DIEA}$ (6:6:12 equiv to the peptide) reagents for $24 \mathrm{~h}$. The solvent was evaporated and the remaining oily product was dissolved in eluent A and purified by RPHPLC. After liophylization the purified product was dried further in dessicator over $\mathrm{P}_{2} \mathrm{O}_{5}$ and then the $\mathrm{ClZ}$ group from the side chain of Lys residue was removed by HF cleavage (HF $-p$ cresol $=10 \mathrm{~mL}: 1 \mathrm{~g})$. The crude product was purified by semi-preparative RP-HPLC and analyzed by analytical HPLC and mass spectrometry (Table 1. and Supporting Information).

\section{Synthesis of Ac-c[CNGRC]-NH $\mathrm{NH}_{2}$ cyclic peptide (2) with disulfide bridge (air oxidation)}

The linear precursor peptide was synthesized on Rink-Amide MBHA resin (0.5 g) with Fmoc $/{ }^{t} \mathrm{Bu}$ strategy as it was described above. Trytyl (Trt) group was used for the side chain protection of Fmoc-cysteine derivative. At the end of the synthesis the N-terminus was acetylated with $\mathrm{Ac}_{2} \mathrm{O}-\mathrm{DIEA}-\mathrm{DMF}(1: 1: 3, \mathrm{v} / \mathrm{v} / \mathrm{v})$ mixture. The peptide was cleaved from the resin as it was described above. Prior to the disulfide bond formation, the crude linear peptide was purified by RP-HPLC. The cyclization was carried out by air oxidation in $0.1 \mathrm{M}$ Tris buffer ( $\mathrm{pH} 8.1$ ) at $0.2 \mathrm{mg} / \mathrm{mL}$ peptide concentration for 24 or $48 \mathrm{hrs}$. The reaction mixture was 
acidified by $\mathrm{HCl}$ solution and concentrated by liophylization. The remaining product was dissolved in eluent A and purified by semi-preparative HPLC. The purified cyclic peptide was characterized by analytical HPLC and mass spectrometry (Table 1 and Supporting Information).

\section{Synthesis of Ac-c[CNGRC]-NH $\mathrm{NH}_{2}$ cyclic peptide (2) with disulfide bridge (oxidation with $\left.\mathbf{T l}(\mathbf{t f a})_{3}\right)$}

In this case Fmoc-Cys(Acm)-OH was applied for the synthesis of linear precursor peptide. For the disulfide bridge formation the $\mathrm{Ac}-\mathrm{Cys}(\mathrm{Acm})-\mathrm{Asn}-\mathrm{Gly}-\mathrm{Arg}-\mathrm{Cys}(\mathrm{Acm})-\mathrm{NH}_{2}$ was dissolved in TFA containing $2 \%$ anisole at $0.2 \mathrm{mg} / \mathrm{mL}$ peptide concentration, then 1.2 equiv $\mathrm{Tl}(\mathrm{tfa})_{3}$ was added to the solution. The oxidation reaction was continued for $1 \mathrm{~h}$ followed by precipitation of the product with dry ether. The crude product was purified by RP-HPLC. The purified cyclic peptide was characterized by analytical HPLC and mass spectrometry (Table 1 and Supporting Information).

\section{Synthesis of c[CH2 CO-XNGRC]-NH2 cyclic peptide (X: Ø (3); Lys (4); Pro (5)) with thioether linkage}

The linear precursor peptides were prepared similarly to the previous compounds on RinkAmide MBHA resin $(0.5 \mathrm{~g})$. The N-terminus of the peptides was chloroacetylated using 5 equiv of chloroacetic acid pentachlorophenyl ester (ClAc-OPcp) that was prepared in our laboratory. ${ }^{38}$ The cleaved chloroacetylated peptides were purified by RP-HPLC prior to the cyclization. The thioether bond was formed in $0.1 \mathrm{M}$ Tris buffer ( $\mathrm{pH} \mathrm{8.1)} \mathrm{as} \mathrm{follows:} \mathrm{the}$ liophylized linear peptides were added to the buffer solution in portions in $2 \mathrm{~h}$. The final peptide concentration was $10 \mathrm{mg} / \mathrm{mL}$ in all cases. The reaction mixtures were allowed to stand for further $1 \mathrm{~h}$ then they were acidified with TFA. The reaction mixture was injected to RP- 
HPLC directly. The purified cyclic peptide was characterized by analytical HPLC and mass spectrometry (Table 1 and Supporting Information).

\section{Synthesis of $\mathrm{c}\left[\mathrm{CH}_{2} \mathrm{CH}_{2} \mathrm{CO}-\mathrm{NGRC}\right]-\mathrm{NH}_{2}$ cyclic peptide (6) with thioether linkage}

In this case 10 equiv $\beta$-chloro- or $\beta$-bromopropionic acid in the presence of equiv DIC and HOBt coupling agents were used for the acylation of the N-terminus of the precursor linear peptide on Rink Amide-MBHA resin (0.5-0.5 g). After cleavage of haloacylated linear peptide from the resin, the crude products were purified by RP-HPLC. The yield of the purified compounds was $20.9 \%$ in case of chloropropionylated and $27.5 \%$ in case of bromopropionylated peptide. The cyclization was carried out in $0.1 \mathrm{M}$ Tris buffer ( $\mathrm{pH} 8.1$ ). The reaction was followed by analytical HPLC. The thioether bond formation was ready within $4 \mathrm{~h}$ in case of $\mathrm{BrCH}_{2} \mathrm{CH}_{2} \mathrm{CO}-\mathrm{NGRC}-\mathrm{NH}_{2}$; however, the reaction was still not complete after $48 \mathrm{~h}$ in case of $\mathrm{ClCH}_{2} \mathrm{CH}_{2} \mathrm{CO}-\mathrm{NGRC}-\mathrm{NH}_{2}$. The yield of the purified cyclic peptides was $33.5 \%$ and $62.3 \%$, respectively, for the chloro- and bromopropionylated linear peptides as precursors (Table 1 and Supporting Information).

\section{Synthesis of $\mathrm{c}\left[\mathrm{CH}_{2} \mathrm{CO}-\mathrm{NGR} h \mathrm{C}\right]-\mathrm{NH}_{2}$ cyclic peptide (7) with thioether linkage}

The synthesis of the homocysteine containing derivative was performed identically to the $\mathrm{c}\left[\mathrm{CH}_{2} \mathrm{CO}-\mathrm{NGRC}\right]-\mathrm{NH}_{2}$ (3) cyclic peptide, but Fmoc- $h \mathrm{Cys}(\mathrm{Trt})-\mathrm{OH}$ was used instead of the cysteine derivative. Characterization of the cyclic peptide is presented in Table 1 and Supporting Information.

\section{Stability studies of the cyclic NGR-peptides}

The study of the storage stability of the liophylized compounds was continued at $4^{\circ} \mathrm{C}$ for 6 months. The solution stability of the compounds was studied in d.i. water, in $0.2 \mathrm{M} \mathrm{NH}_{4} \mathrm{OAc}$ buffer (pH 5.0), PBS solution ( $\mathrm{pH} 7.4)$ and $0.1 \mathrm{M}$ Tris buffer $(\mathrm{pH} 8.1)$ at $1.0 \mathrm{mg} / \mathrm{mL}(\sim 2 \mathrm{mM})$ 
peptide concentration and RT for $48 \mathrm{~h}$. The stability studies of the compounds were also investigated in DMEM GlutaMAX-I (Sigma Ltd., St. Louis, MO, USA) cell culture medium containing 10\% FCS (fetal calf serum, Sigma Ltd.) and gentamicine $(160 \mu \mathrm{g} / \mathrm{mL})$ at the same peptide concentration and $37^{\circ} \mathrm{C}$ for $48 \mathrm{~h}$. The decomposition of the cyclic NGR-peptide derivatives was followed by analytical HPLC.

\section{Structural studies by electronic circular dichroism (ECD) spectroscopy}

ECD spectra $(185<\lambda<300 \mathrm{~nm})$ in water and TFE were recorded on a Jasco J-810 spectropolarimeter at $\mathrm{T}=298 \mathrm{~K}$ using a $0.02 \mathrm{~cm}$ quartz cell. Peptide concentration was set to $0.5-1 \mathrm{mg} / \mathrm{mL}(\sim 1-2 \mathrm{mM})$, each spectra are the average of five subsequent scans. The row spectra were subsequently smoothed by the Means Movement algorithm, final ECD band intensities are expressed in mean residue ellipticity $\left([\Theta]_{\mathrm{MR}}, \mathrm{deg} \mathrm{cm}^{2} / \mathrm{dmol}\right)$.

\section{Structural studies by nuclear magnetic resonance (NMR) spectroscopy}

NMR samples of the all cyclic peptides $(\sim 1 \mathrm{mM})$ were prepared in $\mathrm{H}_{2} \mathrm{O}-\mathrm{D}_{2} \mathrm{O}$ mixture $(9: 1)$ at $\mathrm{pH}$ of $\sim 3$ and $\mathrm{pH} \sim 5$. The NMR experiments were carried out at $288 \mathrm{~K}$ on a Bruker Avance III $700 \mathrm{MHz}$ spectrometer equipped with 5-mm triple-resonance probe-head with z-axis pulsed field gradient. The identification of spin systems and sequence specific assignments were obtained from 2D ${ }^{1} \mathrm{H}-{ }^{1} \mathrm{H}$ ROESY (250 and $\left.350 \mathrm{~ms}\right),{ }^{1} \mathrm{H}-{ }^{1} \mathrm{H}$ TOCSY $(80 \mathrm{~ms})$ and ${ }^{1} \mathrm{H}-{ }^{1} \mathrm{H}$ DQF-COSY spectra at $288 \mathrm{~K}$. NMR data processing was performed by the help of TopSpin 3.1 and the spectra were analyzed using CCPNMR analysis 2.1 software packages. ${ }^{47}$ From the appropriate ROESY spectra a total of 106, 97, 87, 122, 107, 79, and 108 distance restraints were obtained for cyclic peptides containing NGR motif (compounds 1-7, respectively). For the restraints three distance ranges $(0.18-0.25,0.25-0.35$ and $0.35-0.50 \mathrm{~nm})$ were used based on the intensity of corresponding ROESY peaks. Structure calculations were performed using 
the standard simulated annealing protocols with the CNS software package. ${ }^{48,49}$ For each molecule an ensemble of 100 structures were calculated and examined. For chemical shift referencing DSS (2,2-dimethyl-2-sila-pentane-5-sulfonic acid) was used.

\section{Cell and culturing}

The effects of the cyclic NGR-peptides on cell adhesion were evaluated in A2058 human melanoma cell line derived from a brain metastasis. ${ }^{50}$ This cell line shows high metastatic potency, and different substrate-bound, RGD sequence containing extracellular matrix proteins (e.g. laminin, fibronectin) acting along gradient induced directional migration (haptotaxis). ${ }^{45}$

Cultures of A2058 were maintained in RPMI 1640 (Sigma Ltd. St. Louis, MO, USA) containing 10\% FCS (Lonza Group Ltd., Switzerland), L-glutamine (2 mM) (Gibco ${ }^{\circledR} /$ Invitrogen Corporation, New York, NY, USA), $100 \mu \mathrm{g} / \mathrm{mL}$ penicillin/streptomycin $\left(\mathrm{Gibco}^{\circledR} /\right.$ Invitrogen Corporation, New York, NY, USA) at $37^{\circ} \mathrm{C}$ in a humidified $5 \% \mathrm{CO}_{2}$ atmosphere.

\section{Cell adhesion assay}

The adhesion modulator effect of cyclic NGR-peptides on A2058 melanoma cell line was measured by xCELLigence SP System (Roche Applied Science, Indianapolis, IN, USA). This system is a dedicated one to detect the kinetics and strength of cell attachment by monitoring electrical impedance across gold microelectrodes integrated on a bottom of special cell culture plate (E-plate) in real time manner. The detected impedance depends on the number and spreading of cells adhered to the surface of the electrodes. The change in impedance is represented as Cell Index (CI). The CI is a relative and dimensionless value, and calculated by the following formula:

$$
\mathrm{CI}=\frac{\left(\mathrm{Z}_{\mathrm{i}}-\mathrm{Z}_{0}\right)}{F_{\mathrm{i}}}
$$


where $Z_{i}$ is the impedance at an individual point of time during the experiment, $Z_{0}$ is the impedance at the start of the experiment, and $F_{i}$ is a constant depending on the frequency $\left(\mathrm{F}_{10 \mathrm{kHz}}=15\right)$.

The cyclic NGR-peptides were tested in $10^{-8}-10^{-6} \mathrm{M}$ concentration range. The consecutive 10 -fold dilutions of the peptides were made in $0.1 \%$ gelatin (Sigma Ltd. St. Louis, MO, USA) solved in PBS (phosphate buffered saline $\mathrm{pH}=7.4$ ). The surface of the electrode in each well of E-plate was coated by $25 \mu \mathrm{L}$ of different concentrations of NGR-peptides for $20 \mathrm{~min}$ at $4^{\circ} \mathrm{C}$. After the incubation the dilutions of NGR-peptides were removed, and the wells were desiccated for $5 \mathrm{~min}$ at room temperature in sterile condition. To gain a background curve of constant $\mathrm{CI}$ value $100 \mu \mathrm{L}$ of pure cell culture medium was added to each well and the CI was recorded for $30 \mathrm{~min}$. In the following step $10^{4}$ cells/well were loaded on E-plate. The wells coated with $0.1 \%$ gelatin solution without test compound served as a control. The cell adhesion of A2058 cells on NGR-peptide coated surface was monitored in every $20 \mathrm{sec}$ for 25 $\mathrm{h}$ at $10 \mathrm{kHz}$. Each measurement was carried out in triplicates.

The Delta CI values gained at individual time points $(5,10$ and $25 \mathrm{~h})$ were used for data analysis, the integrated software (RTCA 1.2) was applied in calculations. The Delta CI refers to the difference of CI value at time point of cell inoculation and CI value at a given time point. The Delta CI values of each concentration of cyclic NGR-peptides were normalized to the control and were given as Norm. Delta CI (Normalized Delta Cell Index) in percent.

\section{Statistical evaluation of data}

Data shown in the Figure 7 represent averages expressed as percentage of untreated control and \pm SD values. Statistical analysis of data was done by the application of ANOVA of Origin Pro8.0 (OriginLab Corporation, Northampton, MA, USA). The level of significance is shown as follows: $\mathrm{x}-\mathrm{p}<0.05 ; \mathrm{y}-\mathrm{p}<0.01 ; \mathrm{z}-\mathrm{p}<0.001$. 


\begin{abstract}
ASSOCIATED CONTENT
Supporting Information

Additional HPLC chromatograms and mass spectra that demonstrate the purity of the cyclic NGR peptides as well as their decomposition under different circumstances are presented in Supporting Information. Furthermore, some NMR characteristics are added in Supporting Information, too.
\end{abstract}

\author{
AUTHOR INFORMATION \\ * Corresponding Author: \\ Prof. Gábor Mező \\ MTA-ELTE Research Group of Peptide Chemistry \\ Pázmány P. stny. 1/A, 1117 Budapest, Hungary: \\ E-mail: gmezo@,elte.hu \\ Tel.: +36-1-372-2500/1433; Fax: +36-1-372-2620
}

\title{
ACKNOWLEDGMENTS
}

This work was supported by grants from the Hungarian National Science Fund (OTKA, K 104045, K 100720, NK 101072) and by the European Union and the European Social Fund under grant agreements no. TÁMOP-4.2.1.B-11/2/KMR-2011-0002.

\section{REFERENCES}

1. Koivunen, E.; Wang, B.; Ruoslahti, E. Isolation of highly specific ligand for the alpha 5 beta 1 integrin from a phage display library. J. Cell Biol. 1994, 124: 373-380.

2. Healy, J. M.; Murayama, O.; Maeda, T. Yoshino, K.; Sekiguchi, K.; Kikuchi, M. Peptide ligands for integrin alpha $\mathrm{v}$ beta 3 selected from random phage display libraries. Biochemistry 1995, 34, 3948-3955. 
3. Arap, W.; Pasqualini, R.; Ruoslahti, E. Cancer treatment by targeted drug delivery to tumor vasculature in a mouse model. Science 1998, 279, 377-380.

4. Pasqualini, R.; Koivunen, E.; Kain, R.; Lahdenranta, J.; Sakamoto, M.; Stryhn, A.; Ashmun, R. A.; Shapiro, L. H.; Arap, W.; Ruoslahti, E. Aminopeptidase N is a receptor for tumor-homing peptides and a target for einhibiting angiogenesis. Cancer Res. 2000, 60, 722-727.

5. Curnis, F.; Arrigoni, G.; Sacchi, A.; Fischetti, L.; Arap, W.; Pasqualini, R.; Corti, A. Differential binding of drugs containing the NGR motif to CD13 isoforms in tumor vessels, epithelia and myeloid cells. Cancer Res. 2002, 62, 867-874.

6. Luan, Y.; Xu, W. The structure and main functions of aminopeptidase N. Curr. Med. Chem. 2007, 14, 639-647.

7. Corti, A.; Curnis, F.; Arap, W.; Pasqualini, R. The neovasculature homing motif NGR: more than meets the eye. Blood 2008, 112, 2628-2635.

8. Corti, A.; Curnis, F. Tumor vasculature targeting through NGR-peptide-based drug delivery systems. Curr. Pharm. Biotechnol. 2011, 12, 1128-1134.

9. Wickström, M.; Larsson, R.; Nygren, P.; Gullbo, J. Aminopeptidase N (CD13) as a target for cancer chemotherapy. Cancer Sci. 2011, 102, 501-508.

10. Geiger, T.; Clarke, S. Deamidation, isomerisation, and racemisation at asparaginyl and aspartyl residues in peptides. J. Biol. Chem. 1987, 262, 785-794.

11. Stephenson, R. C.; Clarke, S. Succinimide formation from aspartyl and asparaginyl peptides as a model for the spontaneous degradation of proteins. J. Biol. Chem. 1989, $264,6164-6170$.

12. Wakankar, A. A.; Borchardt, R. T. Formulation considerations for proteins susceptible to asparagine deamidation and aspartate isomerisation. J. Pharm. Sci. 2006, 95, 23212336. 
13. Curnis, F.; Cattaneo, A.; Longhi, R.; Sacchi, A.; Gasparri, A. M.; Pastorino, F.; Di Matteo, P.; Traversari, C.; Bachi, A.; Ponzoni, M.; Rizzardi, G. P.; Corti, A. Critical role of flanking residues in NGR-to-isoDGR transition and CD13/Integrin receptor switching. J. Biol. Chem. 2010, 285, 9114-9123.

14. Patel, K.; Borchardt, R. T. Chemical pathways of peptide degradation. III. Effect of primary sequence on pathways of deamidation of asparaginyl residues in hexapeptide. Pharm. Res. 1990, 7, 787-793.

15. Tyler-Cross, R.; Schirch, V. Effects of amino acid sequence, buffers, and ionic strength on the rate and mechanism of deamidation of asparagine residues in small peptides. J. Biol. Chem. 1991, 266, 22549-22556.

16. Stevenson, C. L.; Friedman, A. R.; Kubiak, T. M.; Donlan, M. E.; Borchardt, R. T. Effect of secondary structure on the rate of deamidation of several growth hormone releasing factor analogs. Int. J. Pept. Prot. Res. 1993, 42, 497-503.

17. Xie, M.; Schowen, R. L. Secondary structure and protein deamidation. J. Pharm. Sci. 1999, $88,8-13$.

18. Xie, M.; Aube, J.; Borchardt, R. T.; Morton, M.; Topp, E. M.; Vandar Velde, D.; Schowen, R. L. Reactivity toward deamidation of asparagine residues in beta-turn structures. J. Pept. Res. 2000, 56, 165-171.

19. Capasso, S.; Balboni, G.; Di Cerbo, P. Effect of lysine residues on the deamidation reaction of asparagine side chain. Biopolymers 2000, 53, 213-219.

20. Plesniak, L. A.; Salzameda, B.; Hinderberger, H.; Regan, E.; Kahn, J.; Mills, S. A.; Teriete, P.; Yao, Y.; Jennings, P.; Marassi, F.; Adams, J. A. Structure and activity of CPNGRC: a modified CD13/APN peptidic homing motif. Chem. Biol. Drug Des. 2010, 75, 551-562. 
21. Curnis, F.; Sacchi, A.; Borgna, L.; Magni, F.; Gasparri, A.; Corti, A. Enhancment of tumor necrosis factor alpha antitumor immunotherapeutic properties by targeted delivery to aminopeptidase N (CD13) Nat. Biotechnol. 2000, 18, 1185-1190.

22. Colombo, G.; Curnis, F.; De Mori, G. M.; Gasparri, A.; Longoni, C.; Sacchi, A.; Longhi, R.; Corti, A. Structure-activity relationship of linear and cyclic peptides containing NGR tumor-homing motif. J. Biol. Chem. 2002, 277, 47891-47897.

23. Sacchi, A.; Gasparri, A.; Curnis, F.; Bellone, M.; Corti, A. Crucial role for interferon gamma in the synergism between tumor vasculature-targeted tumor necrosis alpha (NGR-TNF) and doxorubicin. Cancer Res. 2004, 64, 7150-7155.

24. Curnis, F.; Gasparri, A.; Sacchi, A.; Cattaneo, A.; Magni, F.; Corti, A. A target delivery of IFNgamma to tumor vessels uncouples antitumor from counterregulatory mechanism. Cancer Res. 2005, 65, 2906-2913.

25. Crippa, L; Gasparri, A.; Sacchi, A.; Ferrero, E.; Curnis, F.; Corti, A. Synergistic damage of tumor vessels with ultra low-dose endothelial-monocyte activating polypeptide-II and neovasculature-targeted tumor necrosis factor-alpha. Cancer Res. 2008, 68, 1154-1161.

26. Pastorino, F.; Brignole, C.; Marimpietri, D.; Cilli, M.; Gambini, C.; Ribatti, D.; Longhi, R.; Allen, T. M.; Corti, A.; Ponzoni, M. Vascular damage and anti-angiogenic effects of tumor vessel-targeted liposomal chemotherapy. Cancer Res. 2003, 63, $7400-7409$.

27. Pastorino, F.;, Brignole, C.; Di Paolo, D.; Nico, B.; Pezzolo, A.; Marimpietri, D.; Pagnan, G.; Piccardi, F.; Cilli, M.; Longhi, R.; Ribatti, D.; Corti, A.; Allen, T. M.; Ponzoni, M. Targeting liposomal chemotherapy via both tumor cell-specific and tumor vasculature-specific ligands potentiates therapeutic efficacy. Cancer Res. 2006, 66, $10073-10082$. 
28. Ndinguri, M. W.; Solipuram, R.; Gambrell, R. P.; Aggarwal, S.; Hammer, R. P. Peptide targeting of platinum anti-cancer drugs. Bioconjug. Chem. 2009, 20, 18691878.

29. Luo, L. M.; Huang, Y.; Zhao, B. X.; Zhao, X.; Duan, Y.; Du, R.; Yu, K. F.; Song, P.; Zhao, Y.; Zhang, X.; Zhang, Q. Anti-tumor and anti-angiogenic effect of metronomic cyclic NGR-modified liposomes containing paclitaxel. Biomaterials 2013, 34, 1102 1114 .

30. Chen, K.; Ma, W.; Li, G.; Wang, J.; Yang, W.; Yap, L. P.; Hughes, L. D.; Park, R.; Conti, P. S. Synthesis and evaluation of $64 \mathrm{Cu}$-labeled monomeric and dimeric NGRpeptides for MicroPET imaging of CD13 receptor expression. Mol. Pharm. 2013, 10, $417-427$.

31. Ma, W.; Kang, F.; Wang, Z.; Yang, W.; Li, G.; Ma, X.; Li, G.; Chen, K.; Zhang, Y.; Wang, J. (99m)Tc-labeled monomeric and dimeric NGR-peptides for SPECT imaging of CD13 receptor in tumor-bearing mice. Amino Acids 2013, 44, 1337-1345.

32. Dunn, M.; Zheng, J.; Rosenblat, J.; Jaffray, D. A.; Allen, C. APN/CD13-targeting as a strategy to alter the tumor accumulation of liposomes. J. Control. Release 2011, 154, $298-305$.

33. Negussie, A. H.; Miller, J. L.; Reddy, G.; Drake, S. K.; Wood, B. J.; Dreher, M. R. Synthesis and in vitro evaluation of cyclic NGR-peptide targeted thermally sensitive liposome. J. Control. Release 2010, 143, 265-273.

34. Corti, A.; Ponzoni, M. Tumor vascular targeting with tumor necrosis factor alpha and chemotherapeutic drugs. Signal Transduction and Communication in Cancer Cells 2004, 1028, 104-112.

35. Marelli, U. K.; Rechenmacher, F.; Sobahi, T. R.; Mas-Moruno, C.; Kessler, H. Tumor targeting via integrin ligands. Front. Oncol. 2013, 3, Article 222. 
36. Zou, M.; Zhang, L.; Xie, Y.; Xu, W. NGR-based strategies for targeting delivery of chemotherapeutics to tumor vasculature. Anticancer Agents Med. Chem. 2012, 12, $239-246$.

37. Tugyi, R.; Mező, G.; Fellinger, E.; Andreu, D.; Hudecz, F. The effect of cyclization on the enzymatic degradation of herpes simplex virus glycoprotein D derived epitope peptide. J. Pept. Sci. 2005, 11, 642-649.

38. Jakab, A.; Schlosser, G.; Feijlbrief, M.; Welling-Wester, S.; Manea, M.; Vila-Perello, M.; Andreu, D.; Hudecz, F.; Mező, G. Synthesis and antibody recognition of cyclic epitope peptides, together with their dimer and conjugated derivatives based on residues 9-22 of herpes simplex virus type 1 glycoprotein D. Bioconjug. Chem. 2009, 20, 683-692.

39. Perczel, A.; Hollósi, M. Turns (In: G. D. Fasman editor, Circular Dichroism and the Conformational Analysis of Biomolecules, Plenum Press, New York) 1996, 285-380.

40. Vass, E.; Majer, Zs.; Köhalmy, K.; Hollósi, M. Vibrational and chiroptical spectroscopic characterization of $\gamma$-turn model cyclic tetrapeptides containing two $\beta$ Ala residues. Chirality 2010, 22, 762-771.

41. Bürgi, H. B.; Dunitz, J. D.; Lehn, J. M.; Wipff G. Stereochemistry of reaction paths at carbonyl centres. Tetrahedron 1974, 30, 1563-1572.

42. Perczel, A.; Ángyán, J. G.; Kajtár, M.; Viviani, W.; Rivail, J. L.; Marcoccia, J. F.; Csizmadia, I. G. Peptide models 1. Topology of selected peptide conformational potential-energy surfaces (glycine and alanine derivatives). JACS 1991, 113, 62566265.

43. Spitaleri, A.; Mari, S.; Curnis, F.; Traversari, C.; Longhi, R.; Bordignon, C.; Corti, A.; Rizzardi, G.P.; Musco, G. Structural basis for the interaction of isoDGR with the RGD-binding site of alphavbeta3 integrin. J. Biol. Chem. 2008, 283, 19757-19768. 
44. Bochen, A.; Marelli, U. K.; Otto, E.; Pallarola, D.; Mas-Moruno, C.; Di Leva, F. S.; Boehm, H.; Spatz, J. P.; Novellino, E.; Kessler, H.; Marinelli, L. Biselectivity of isoDGR peptides for fibronectin binding integrin subtypes $\alpha 5 \beta 1$ and $\alpha \mathrm{v} \beta 6$ : conformational control through flanking amino acids. J. Med. Chem. 2013, 56, 15091519.

45. Aznavoorian, S.; Stracke, M. L.; Krutzsch, H.; Schiffmann, E.; Liotta, L. A. Signal transduction for chemotaxis and haptotaxis by matrix molecules in tumor cells. J. Cell Biol. 1990, 110, 1427-1438.

46. Soudy, R.; Ahmed, S.; Kaur, K. NGR-peptide ligands for targeting CD13/APN identified through peptide array screening resemble fibronectin sequences. ACS Comb. Sci. 2012, 14, 590-599.

47. Vranken, W. F.; Boucher, W.; Stevens, T. J.; Fogh, R. H.; Pajon, A.; Llinas, M.; Ulrich, E. L.; Markley, J. L.; Ionides, J.; Laue, E. D. The CCPN data model for NMR spectroscopy: development of a software pipeline. Proteins 2005, 59, 687-696.

48. Brunger, A. T.; Adams, P. D.; Clore, G. M.; Gros, P.; Grosse-Kunstleve, R. W.; Jiang, J. S.; Kuszewski, J.; Nilges, N.; Pannu, N. S.; Read, R. J.; Rice, L. M.; Simonson, T.; Warren, G. L. Crystallography \& NMR System (CNS), A new software suite for macromolecular structure determination. Acta Cryst.1998, D54, 905-921.

49. Brunger, A. T. Version 1.2 of the Crystallography and NMR System. Nat. Protocols 2007, 2, 2728-2733.

50. Todaro, G. J.; Fryling, C.; De Larco, J. E. Transforming growth factors produced by certain human tumor cells: polypeptides that interact with epidermal growth factor receptors. Proc. Natl. Acad. Sci. U S A. 1980, 77, 5258-5262. 


\section{Graphical abstract}

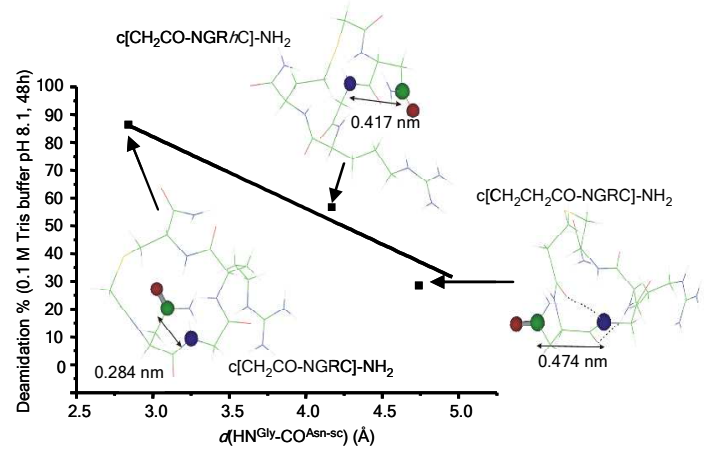

16

17

18

19

20

21

22

23

24

25

26

27

28

29

30

31

32

33

34

35

36

37

38

39

40

41

42

43

44

45

46

47

48

49

50

51

52

53

54

55

56

57

58

59

60 


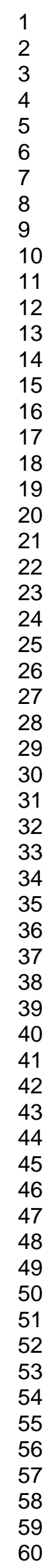

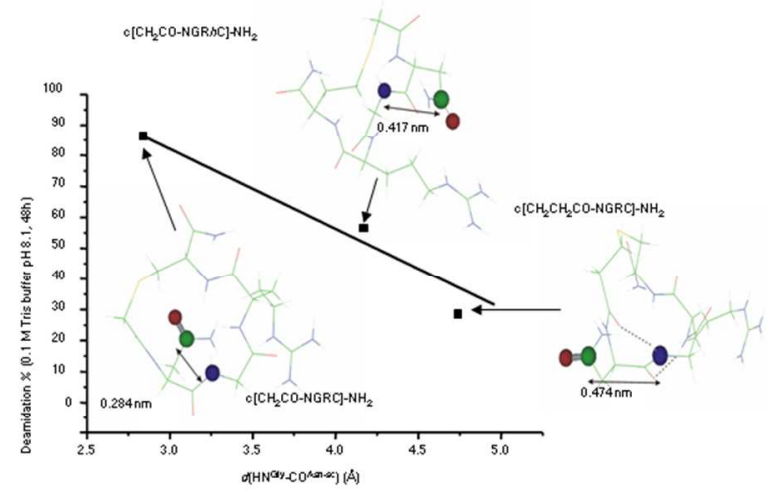

$254 \times 190 \mathrm{~mm}(96 \times 96 \mathrm{DPI})$ 